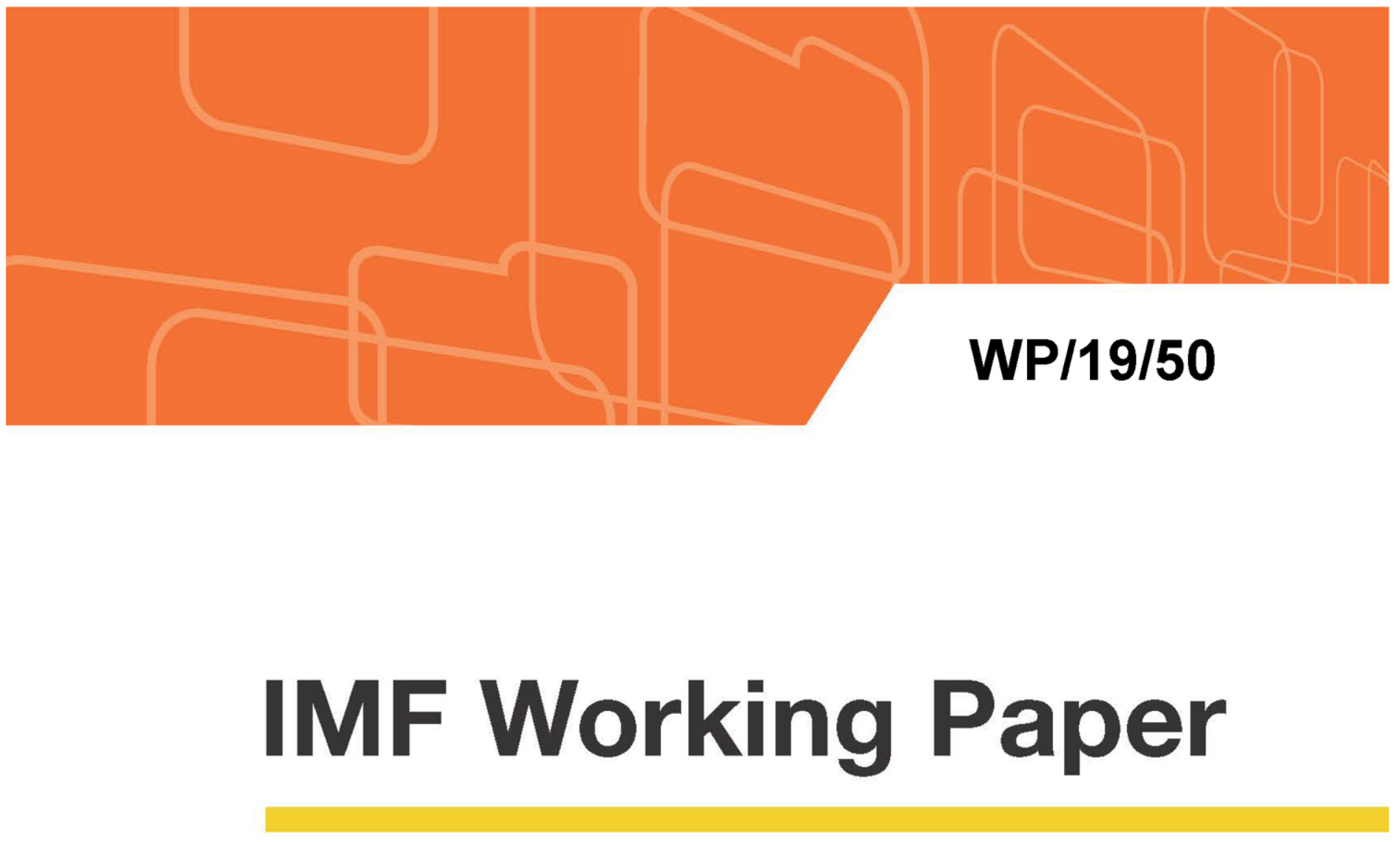

\title{
China's Evolving Exchange Rate Regime
}

by Sonali Das

IMF Working Papers describe research in progress by the author(s) and are published to elicit comments and to encourage debate. The views expressed in IMF Working Papers are those of the author(s) and do not necessarily represent the views of the IMF, its Executive Board, or IMF management. 


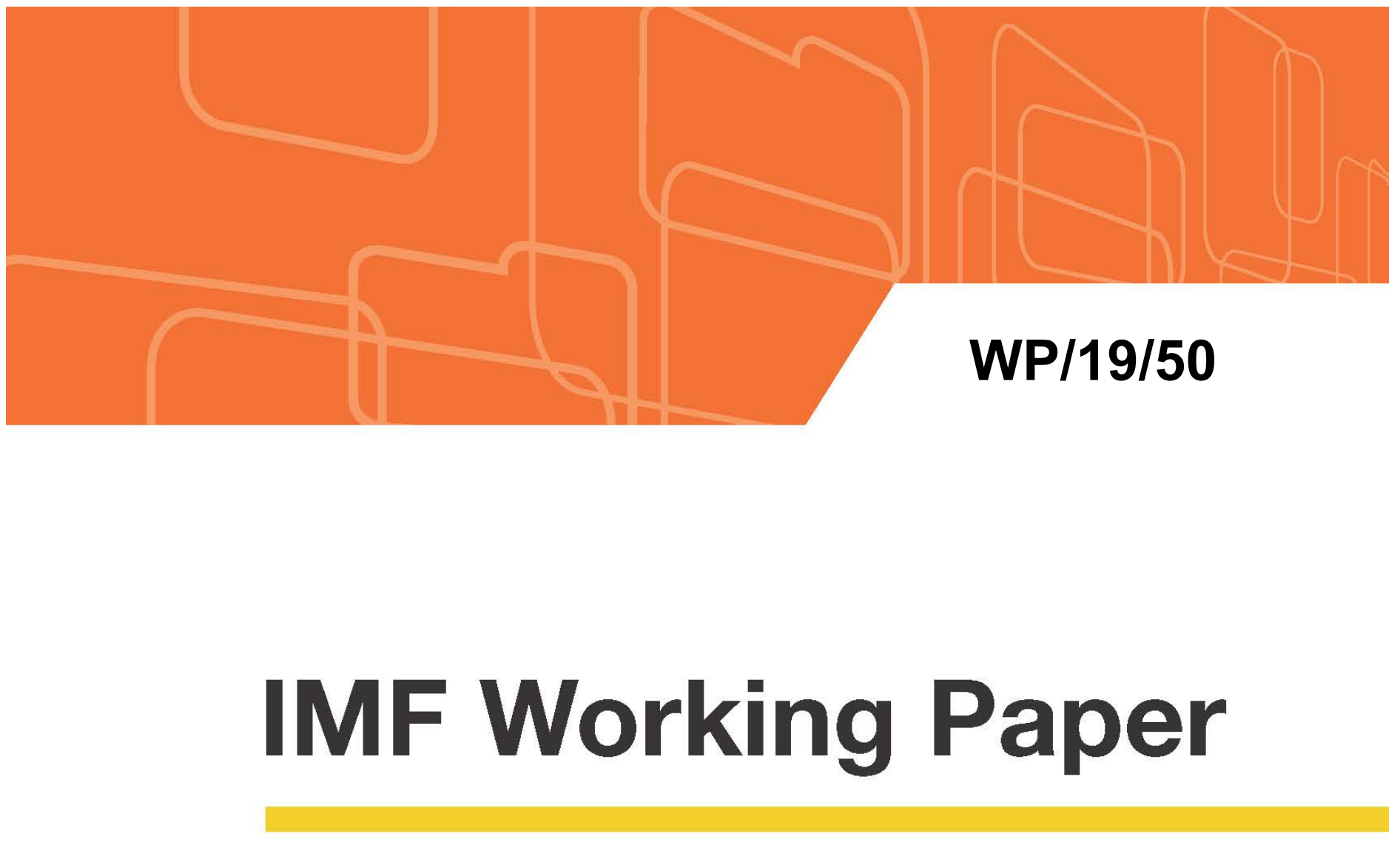

\title{
China's Evolving Exchange Rate Regime
}

\author{
by Sonali Das
}

IMF Working Papers describe research in progress by the author(s) and are published to elicit comments and to encourage debate. The views expressed in IMF Working Papers are those of the author(s) and do not necessarily represent the views of the IMF, its Executive Board, or IMF management.

I N T E R N A T I O N A L M O N E T A R Y F U N D 


\title{
IMF Working Paper
}

\author{
Asia and Pacific Department \\ China's Evolving Exchange Rate Regime ${ }^{1}$ \\ Prepared by Sonali Das \\ Authorized for distribution by James Daniel
}

March 2019

\begin{abstract}
IMF Working Papers describe research in progress by the author(s) and are published to elicit comments and to encourage debate. The views expressed in IMF Working Papers are those of the author(s) and do not necessarily represent the views of the IMF, its Executive Board, or IMF management.
\end{abstract}

\begin{abstract}
China's exchange rate regime has undergone gradual reform since the move away from a fixed exchange rate in 2005. The renminbi has become more flexible over time but is still carefully managed, and depth and liquidity in the onshore FX market is relatively low compared to other countries with de jure floating currencies. Allowing a greater role for market forces within the existing regime, and greater two-way flexibility of the exchange rate, are important steps to build on the progress already made. This should be complemented by further steps to develop the FX market, improve FX risk management, and modernize the monetary policy framework.
\end{abstract}

JEL Classification Numbers: F31, F33, G15, O16, N20

Keywords: reminbi, exchange rate, foreign exchange market, liquidity

Author's E-Mail Address: sdas2@imf.org

\footnotetext{
${ }^{1}$ I am grateful to James Daniel, Ding Ding, Simon Gray, Sonali Jain-Chandra, Kenneth Kang, and Markus Rodlauer for helpful comments.
} 


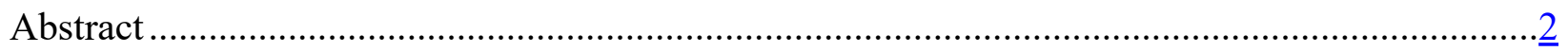

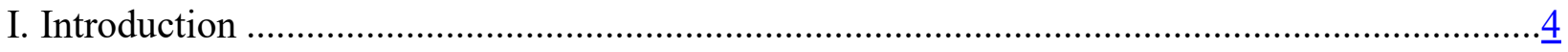

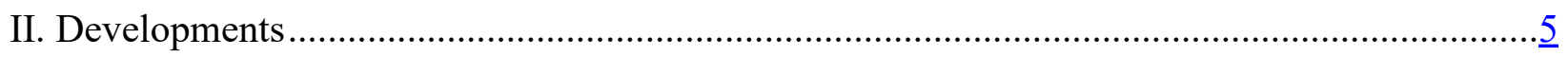

A. Move away from a fixed exchange rate, continued stability with respect to the U.S. dollar

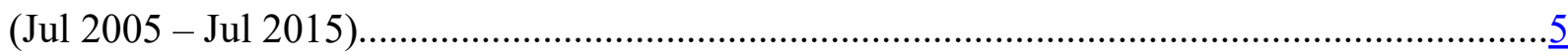

B. Attempt at increasing flexibility, market turbulence, followed by managed depreciation

(Aug 2015 - Dec 2016)......................................................................................... 9

C. Stability against the CFETS basket of currencies (mid-2016 to end-2017).......................12

D. The current regime: Increasing moves towards flexibility .......................................13

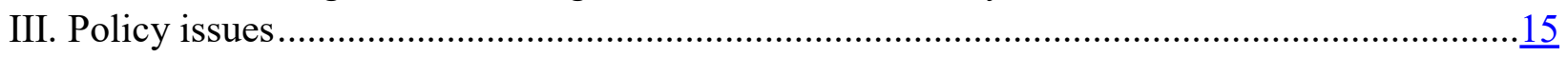

A. What should China's exchange rate regime be in the longer-term? ................................15

B. Fear of floating - Is China different? .....................................................................16

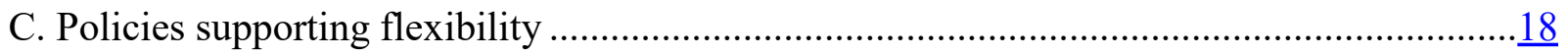

Developing a liquid and deep FX market .......................................................... 18

Capacity to regulate, monitor, and manage exchange rate risks ....................................20

An appropriate alternative nominal anchor and developing supporting markets ................22

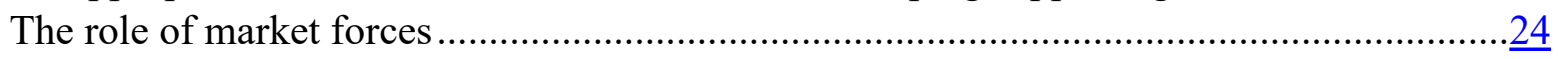

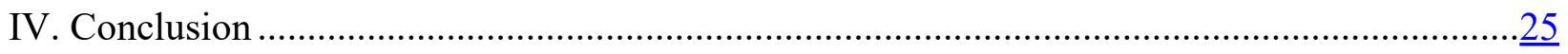

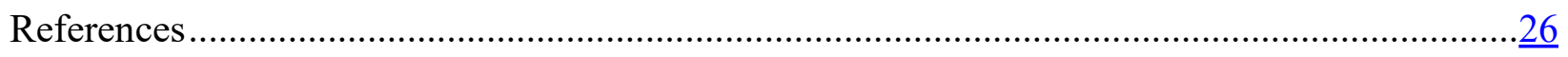

Annex I. BRIICS Currencies - Volume traded by Price ...................................................... 28

Annex II. Examples from international experience .......................................................29 


\section{INTRODUCTION}

China's exchange rate regime has undergone gradual reform. After announcing the move away from a fixed exchange rate in July 2005, China began taking regular steps towards a more flexible currency, while exchange rate stability continued to play an important role. The exchange rate has become more flexible over time but is still carefully managed. A flexible, market-determined exchange rate is needed to help absorb external shocks and maintain the People's Bank of China's (PBC) ability to use monetary policy to affect domestic economic conditions. As China is in a key stage of its transition towards a floating exchange rate, examining past developments and current conditions helps to understand the path forward. This paper provides an overview of the evolution of China's exchange rate regime from 2005 onwards, lays out the unique constraints faced by China on its path to a floating exchange rate, and analyzes the supporting conditions and policies needed for a smooth adjustment. Key constraints to greater flexibility specific to China stem from: the large pool of renminbi (RMB) savings seeking diversification, herding behavior that creates a vulnerability to large depreciation events, and the potential for sudden RMB movements to lead to regional spillovers.

\section{Key recommendations to support the transition to greater exchange rate flexibility are:}

- Allow a greater role for market forces in the current exchange rate regime: Make central parity formation for the daily trading band (the 'fix') mechanical and transparent; the use of FX intervention should be guided by the need to limit excessive volatility; and capital flow management measures (CFMs) should not be modulated to help manage the exchange rate.

- Deepen the foreign exchange (FX) market: This should include concrete steps to phase out regulations that stifle FX market activity, such as the reserve requirement on forwards. A key step at this stage is also to allow more exchange rate flexibility.

- Improve management of $\mathrm{FX}$ risks: Allow exchange rate flexibility to create a sense of two-way risk; educate market participants about FX risks; and encourage hedging.

- Develop an alternate monetary policy anchor: The PBC should be granted operational independence and

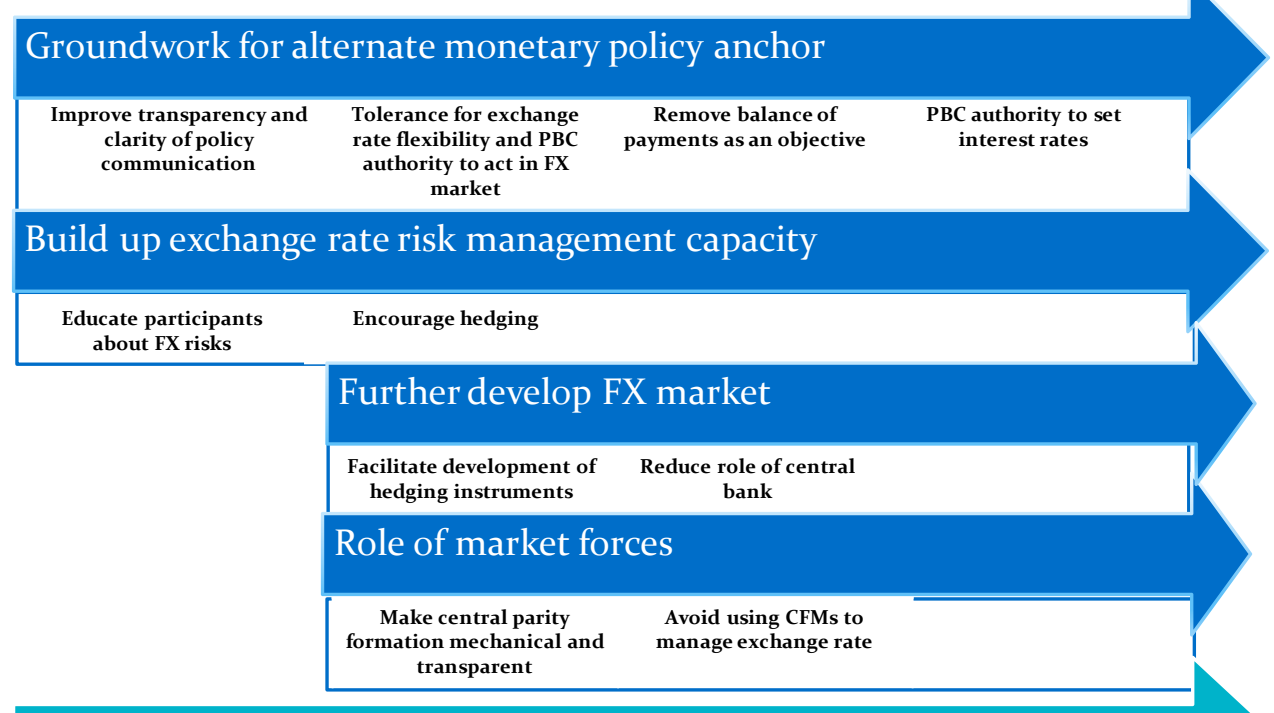

Increasing exchange rate flexibility in tandem with above reforms 
develop an explicit policy interest rate, subject to the longer-term goals for monetary policy set by the government. The interest-rate based policy framework should be strengthened and the clarity and frequency of communication further increased.

The paper is organized as follows. Section II provides an overview of the changes in China's exchange rate regime since July 2005, categorizing the developments into four distinct regimes. Section III then discusses the issues of relevance for policy makers: the longer-term exchange rate regime, constraints to flexibility, and policies to support the ongoing move to a flexible exchange rate. Section IV concludes.

\section{DEVELOPMENTS}

\section{A. Move away from a fixed exchange rate, continued stability with respect to the U.S. dollar} (Jul 2005 - Jul 2015)

Reform undertaken to increase the flexibility of the exchange rate regime. On July 21, 2005, China announced a major reform to its exchange rate regime, from fixing the yuan rate with respect to the U.S. dollar to a more flexible arrangement. The PBC announced that China was "moving into a managed floating exchange rate regime based on market supply and demand with reference to a basket of currencies." The basket of currencies was not specified, however, and the announced regime was one with a continued tight link to the U.S. dollar. Specifically, there would be a daily rate (the central parity rate, also known as the 'fix') announced before the start of the trading day that would form the midpoint of the band within which the RMB/USD rate could fluctuate on that day. Specifically: ${ }^{2}$

- The central parity mechanism was established, with the RMB/USD rate allowed to fluctuate in a daily band of $+/-0.3$ percent around the central parity, which was the previous day's close.

- The yuan would be permitted to fluctuate within a wider band, of $+/-1.5$ percent, against the other foreign currencies traded in the interbank market: the Euro, Hong Kong dollar, and Yen.

- The plan was to increase exchange rate flexibility over time, as the PBC would "make adjustment of the RMB exchange rate band when necessary according to market development as well as the economic and financial situation."

\footnotetext{
${ }^{2}$ See PBC announcement on "Reforming the RMB Exchange Rate Regime," July 21, 2005. www.pbc.gov.cn/english/130721/2831438/index.html
} 
The July 2005 reform was accompanied by a 2.1 percent step revaluation of the RMB/USD rate, to 8.11 yuan per dollar. The revaluation and reform were based on the understanding that the previous exchange rate arrangement, a conventional fixed peg to the U.S. dollar, was unsustainable and undesirable for responding, without disruptive episodes of inflation or deflation, to real-side shocks as well as to secular changes in the economy such as real appreciation due to Balassa-Samuelson effects (Obstfeld 2007). Short-term flexibility was limited in the decade after the reform, and the exchange rate was managed to appreciate gradually against the U.S. dollar, except for during the global financial crises when the

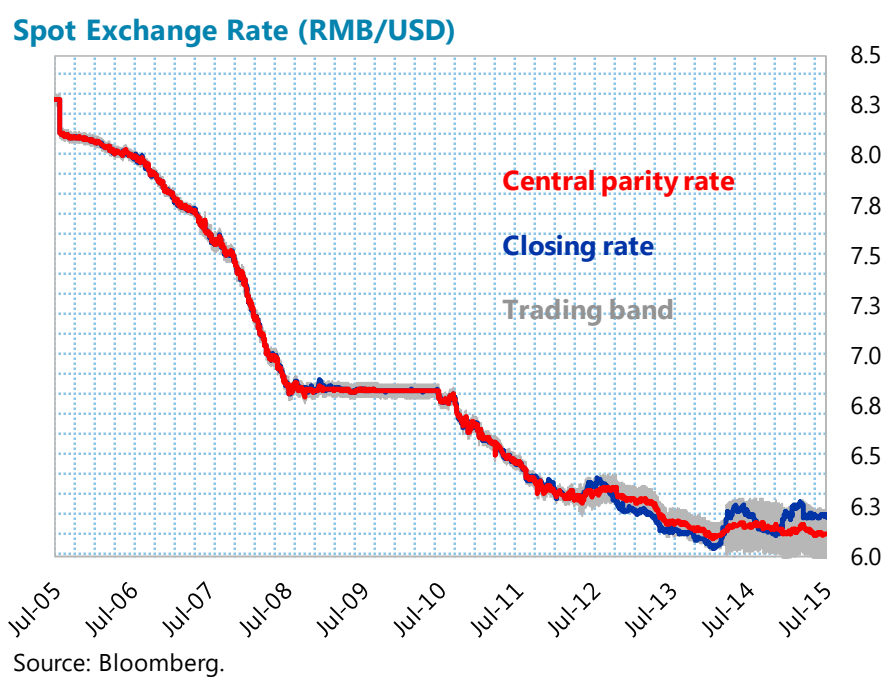
$\mathrm{RMB} / \mathrm{USD}$ rate was kept stable.

Fine-tuning of the central parity rate and band mechanism. In the following years there was a progressive fine-tuning of the central parity and band mechanism. The changes include:

- In September 2005, the trading band for non-U.S. dollar currencies was widened to +/- 3 percent.

- In January 2006, the formation of the daily central RMB/USD parity rate was changed. It was to be calculated as a trimmed weighted average of quotes received from market-making banks before the start of the trading day, with the quotes being based on banks' views of market supply and demand. ${ }^{3}$

- In May 2007, the daily band around the central RMB/USD parity was widened to $+/-0.5$ percent. It was widened further to $+/-1$ percent in April 2012, and +/-2 percent in March

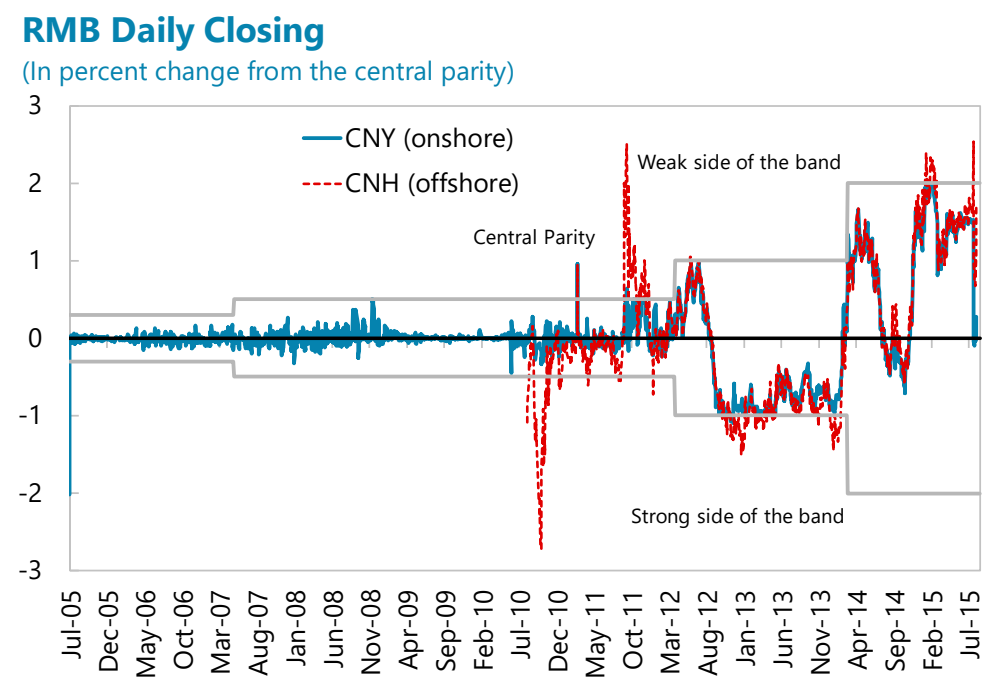
2014.

\footnotetext{
${ }^{3}$ Quotes are given to and the central parity rate is announced by China Foreign Exchange Trading System (CFETS), China's interbank currency market, which is an affiliate of PBC.
} 
- In addition, steps to liberalize and develop China's foreign exchange markets, including the establishment markets for currency forwards and swaps and expanding the number of market participants took place.

Flexibility of the exchange rate put on hold during the global financial crisis. After putting aside the goal of a managed floating exchange rate to focus on a stable RMB/USD during the global financial crisis, the authorities announced a renewed emphasis on exchange rate flexibility in June 2010, although there were no changes made to the de jure exchange rate system. ${ }^{4}$

\section{The exchange rate did not exhibit the properties of a floating regime in practice. While the $\mathrm{PBC}$} announced that the exchange rate regime would be a "managed floating" regime ${ }^{5}$ from July 2005 , the RMB exchange rate was considerably less volatile than other floating exchange rates. ${ }^{6}$ The RMB/USD rate was fairly stable on a daily basis and the range of flexibility permitted was not used, with the daily changes in the RMB/USD rate generally not nearing the edges of the band. ${ }^{7}$ Moreover, the central parity rate barely moved from day to day, even though the spot rate often closed at a distance from the day's central parity rate. China intervened heavily in the foreign exchange market during this period to moderate currency appreciation, with FX reserves increasing from US\$ 733 billion in July 2005 to a peak of US\$ 3.99 trillion in June 2014. The RMB exchange rate with China's other major trading partners, Europe and Japan, was significantly more volatile than the RMB/USD rate.

4 See PBC announcement on "Further Reform the RMB Exchange Rate Regime and Enhance the RMB Exchange
Rate Flexibility PBC" June 19, 2010. www.pbc.gov.cn/english/130721/2845862/index.html

5 The IMF's exchange rate classification system was revised in 2009. The then-existing categories of managed and independent floating were replaced with two new categories: floating and free floating, with clearer definitions. A floating exchange rate is largely market determined, without an ascertainable or predictable path for the rate.

${ }^{6}$ The official classification of China's exchange rate regime, from the IMF's Annual Report on Exchange Arrangements and Exchange Restrictions, has changed several times since 2005. The classification is a de facto classification based on actual exchange rate movements. Although the flexibility of the RMB exchange rate increased somewhat from end-July 2005, its movement remained (well) within a +/-2 percent band so the official classification remained a conventional fixed peg arrangement until August 1, 2006. It was reclassified as a crawling peg until the period of the global financial crisis when the RMB/USD rate was managed, resulting in a reclassification as a stabilized arrangement from June 1, 2008 to June 21, 2010. After this, fluctuations in the RMB/USD rate resumed and the classification reverted to a crawl-like arrangement. From December 24, 2014, the classification was changed to "other managed arrangement", a residual category separate from hard pegs, soft pegs, and floating regimes, due to a renewed period of RMB/USD stability from end-December 2014.

${ }^{7}$ While the daily trading band appears to be narrow, a width of $+/-2$ percent allows for substantial cumulative changes in the exchange rate. 

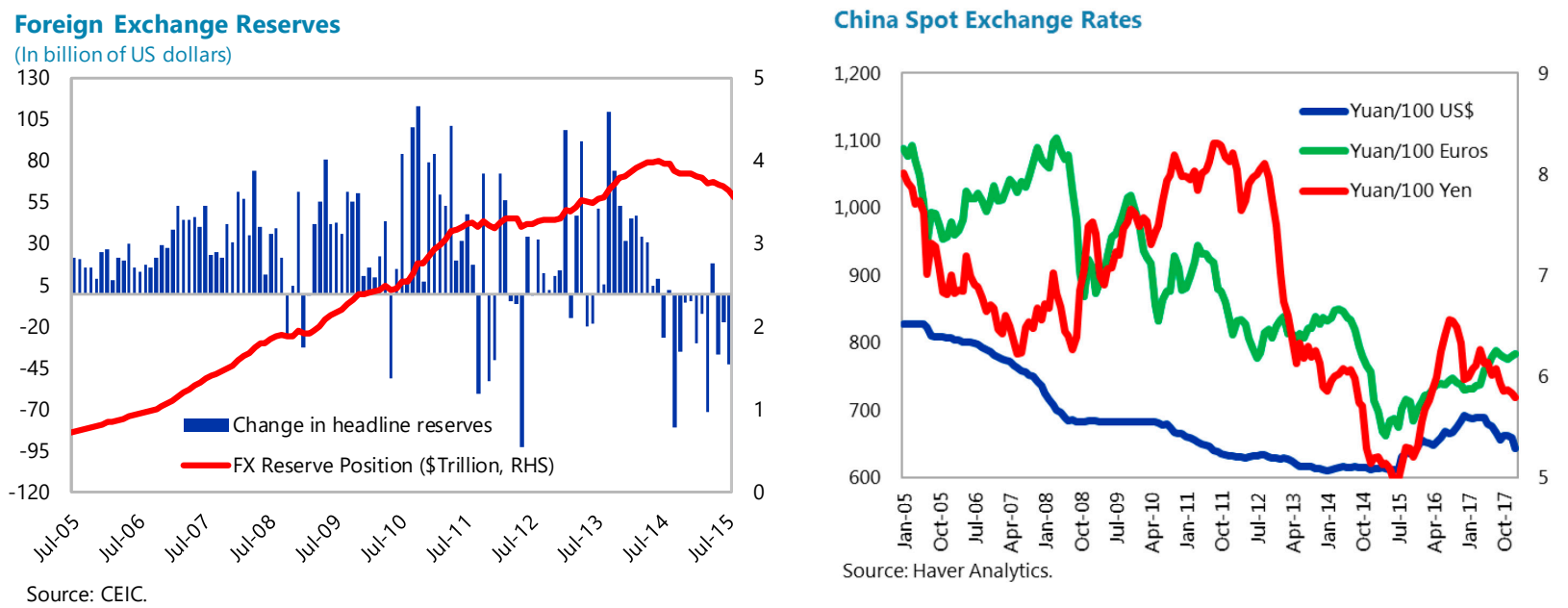

The July 2005 reform announcement described the new regime as an adjustable basket peg, but de facto the regime functioned as a crawling peg to the USD over the following decade. Actual exchange rate movements throughout this period, as well as the lack of information about the reference basket of currencies, led to the perception that the RMB was still essentially linked to the U.S. dollar, though with somewhat more flexibility than before. While the reform announcement indicated the PBC's intention to allow non-U.S. currencies to move within wider ranges than the RMB/USD rate, it appeared to difficult for this to happen in practice, as a large fluctuation in the USD/EUR rate, for example, would require a similarly large change in the RMB/EUR rate or a breach of the RMB/USD limit.

\section{A managed and gradual appreciation relative to the dollar resulted in substantial effective} RMB appreciation from July 2005 to July 2015. Held back by significant FX intervention, there was still substantial, gradual appreciation relative to the dollar and other currencies until July 2015, except for a two-year period following the onset of the global financial crisis when the RMB/USD rate was kept stable. This 'managed' appreciation reflected the authorities' views of a rising equilibrium rate in the context of large external surpluses and productivity increases. The managed appreciation created widespread expectations that the exchange rate would continue in the same direction and led to capital inflows and carry trades. Relative to the U.S. dollar, the RMB appreciated by 26 percent from July 2005 to July 2015; in effective terms, the appreciation was significantly larger (44 percent nominal, 58 percent real).

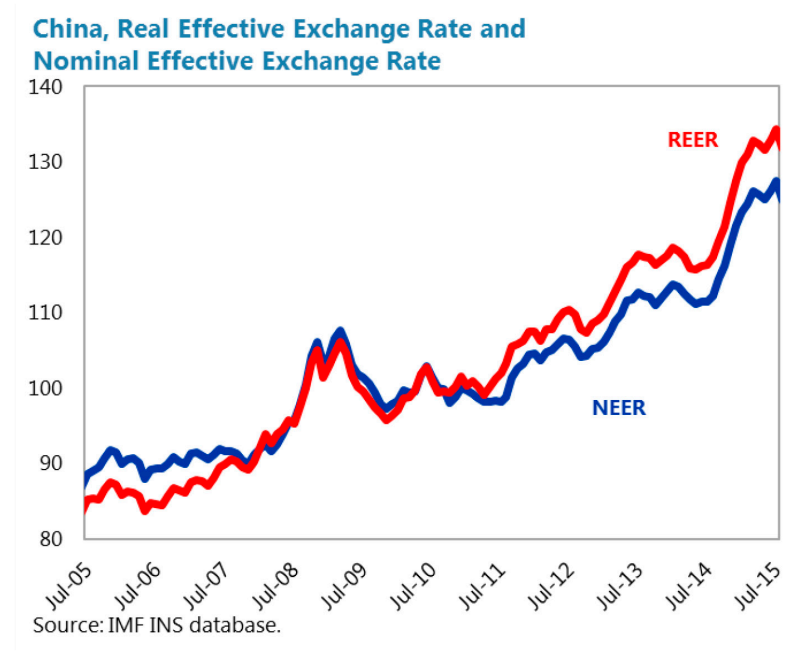


Market sentiment turned in 2014 toward a rising sense that the $R M B$ was becoming overvalued. The RMB's effective appreciation accelerated in late 2014 due to the strength of the U.S. dollar, as the PBC kept the bilateral $\mathrm{RMB} / \mathrm{USD}$ rate broadly stable (with intervention having turned from FX purchases to growing sales). This reinforced market views of RMB overvaluation and capital outflow pressures. The one-year-ahead forward premium on dollars widened steadily in both the onshore market and the offshore (Hong Kong SAR) market for nondeliverable forwards (NDF), from near zero in summer of 2014 to around -3 percent in March 2015. The IMF's 2015 External Sector Report assessed the RMB in the summer of 2015 to no longer be undervalued.

A sharp change to China's balance of payments occurred towards the end of the period. The capital and financial account swung from inflows of almost US\$300 billion in 2013 to outflows of US\$400 billion from mid-2014 to mid-2015, led by a change in short-term investment flows. The current account surplus widened, from 1.5 percent of GDP in 2013 to 2.7 percent of GDP in 2015, due to falling import demand as growth slowed, as well as from terms of trade gains. The growth slowdown in China, with real GDP growth falling from 7.8 percent in 2013 to 7.3 in 2014 and further to 6.9 in 2015, combined with the surge in the U.S. dollar, on expectations of coming increases in U.S. interest rates, underpinned a reversal in pressure on the RMB. FX intervention switched in the summer of 2014 to selling reserves to limit RMB/USD depreciation. The PBC kept the RMB steady against the U.S. dollar, but given the dollar's rise, the RMB appreciated by 14 percent in real effective terms between end-2013 and July 2015.

\section{B. Attempt at increasing flexibility, market turbulence, followed by managed depreciation} (Aug 2015 - Dec 2016)

\section{A brief and unexpected announcement aimed at increasing flexibility sparked confusion} and market turbulence. In a two-sentence announcement made on August 11, 2015, the PBC changed the RMB/USD central parity quoting mechanism, ${ }^{8}$ with the intention of enhancing the market determination of RMB exchange rate. Under the new mechanism, banks were asked to submit quotes that took the closing rate of the previous day into account, in conjunction with market demand and supply and exchange rate movements of major currencies. The announcement was accompanied by a 1.9 percent depreciation of the RMB relative to the dollar.

\footnotetext{
${ }^{8}$ PBC Announcement on Improving Quotation of the Central Parity of RMB against U.S. Dollar, August 11, 2015. http://www.pbc.gov.cn/english/130721/2941603/index.html.
} 
The unexpected change to the regime triggered a surge in global financial market volatility, with the VIX rising to a four year high, and capital outflows accelerating, as many market participants interpreted the change as the beginning of a sizeable RMB depreciation. The RMB/USD rate depreciated by a further 1 percent on August 12, before stabilizing and trading in a very narrow range from mid-August until end-September.

\section{Capital outflows accelerated, both from an unwinding of the carry trade as well as from} capital flight. Capital outflows doubled from an average of around US\$ 100 billion in the third and fourth quarters of 2014 to a quarterly average of US\$ 200 billion in the second half of 2015 . The deterioration in the capital account, a US\$900 billion swing in annual capital account flows between 2013 and 2015, was largely due to three factors: (i) an unwinding of carry trades, (ii) foreign asset acquisition by residents (through official channels), and (iii) some "capital flight" (unrecorded outflows).

- Unwinding carry trades likely represented over half of the swing, as the reversal of residents' net acquisition of external liabilities, in the form of debt repayment, accounted for US\$ 500 billion. Specifically, Chinese external liabilities fell, primarily reflecting the unwinding of loans from non-residents and the repatriation of deposits of non-residents, two key channels for carry trades. This was due to falling interest rates from looser Chinese monetary policy together with the changes in exchange rate expectations.

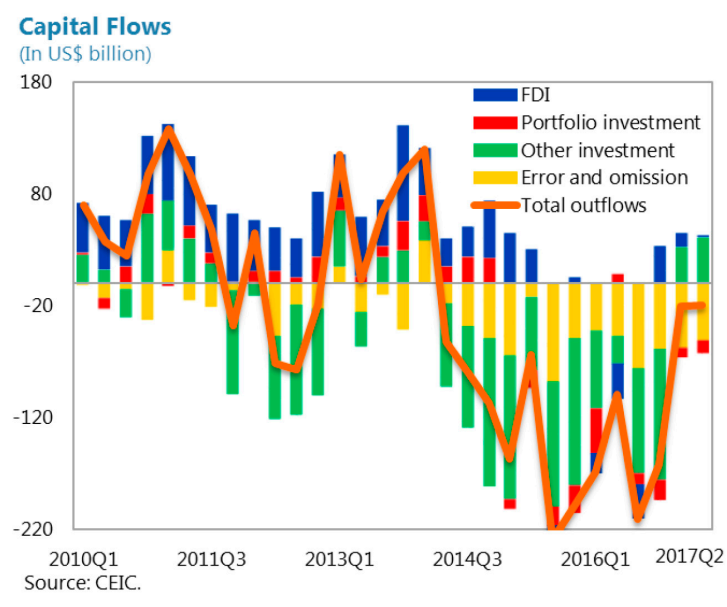

- The rest of the swing in the capital account consisted of an acceleration in the acquisition of foreign assets by residents, both recorded and unrecorded.

The $\mathrm{PBC}$ responded by using $\mathrm{FX}$ intervention to stabilize the exchange rate in conjunction with CFMs to stem outflows. International reserves fell by US\$ 321 billion in the second half of 2015, with some market participants suggesting potentially additional intervention such as by

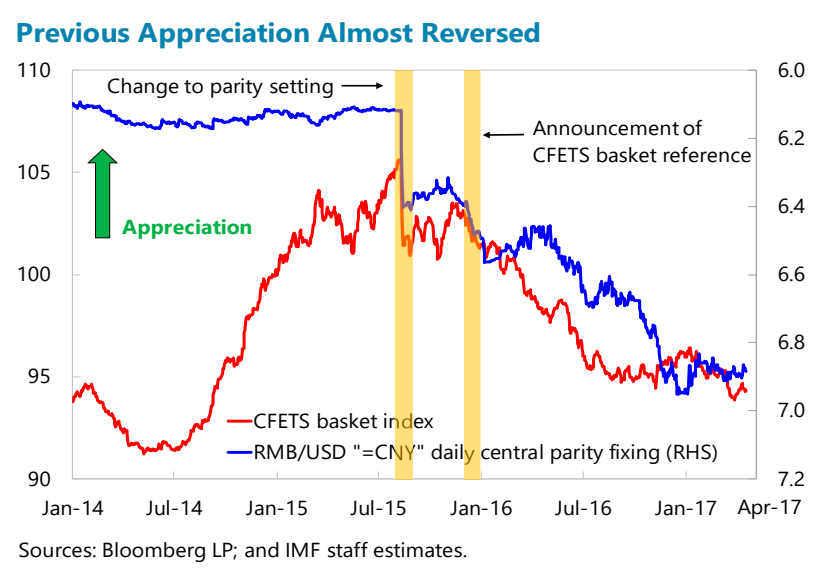

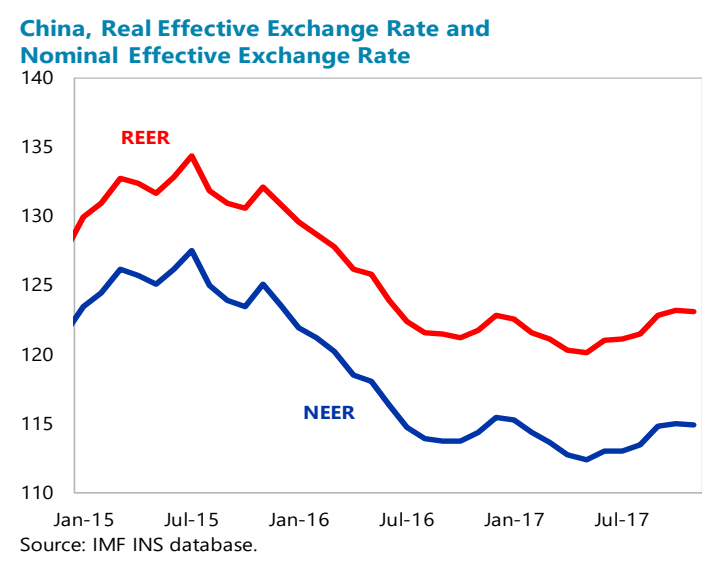


moral suasion. The RMB/USD rate began to depreciate again in December 2015 and early 2016, leading to another round of increased Chinese and global market volatility. Substantial FX intervention in January and February of 2016 followed to stabilize the currency. The REER depreciated by 6.8 percent from August 2015 to December 2016. Enforcement of existing CFMs was tightened, including on overseas direct investment and offshore RMB lending, and some other measures introduced, for example, a reserve requirement on banks' FX forward transactions.

\section{Guidance on the exchange rate regime was developed to clarify the regime and mitigate depreciation expectations. In December 2015, CFETS published the "CFETS exchange rate} index", dating back to December 31, 2014, to guide the market on the basket of currencies that was the focus of policy. ${ }^{9}$ RMB exchange rate indices based on the SDR and the BIS currency baskets were also published. Subsequently, in early 2016, the authorities elaborated on how the new regime was expected to function and reassured markets that they were not targeting or expecting substantial depreciation. They provided guidance to banks on the formulation of their daily RMB/USD central parity quotes. The quotes were to be based on the "previous closing rate plus changes in the currency basket", with the "changes in the currency basket" referring to the adjustment in the RMB/USD rate needed to offset the impact of the changes in cross-rates among basket currencies during the previous trading day and overnight. ${ }^{10,11}$ All three indexes the CFETS index, BIS index, and SDR index - were mentioned but the focus appeared to be on the CFETS index as market makers were instructed to "both consider the CFETS currency basket and refer to the BIS and SDR baskets in a bid to remove the noise among the changes in the currency basket,...".

\footnotetext{
${ }^{9}$ PBC Notice by Guest Commentator of CFETS "The Launch of RMB Index Helps to Guide Public View of RMB Exchange Rate,” December 11, 2015. http://www.pbc.gov.cn/english/130721/2988680/index.html.

10 People's Bank of China (2016), "Improving the RMB/USD Central Parity Formation Mechanism” Monetary Policy Report, Quarter One 2016, pp 52-53. www.pbc.gov.cn/english/resource/cms/2017/03/2017031316550822382.doc
}

${ }^{11}$ According to the quote formula, the previous day's RMB/USD closing rate was to be passed through in full, as was the amount of change against the USD needed to offset the change in the value of the CFETS index due to cross-rate developments during the previous trading day and overnight. Specifically:

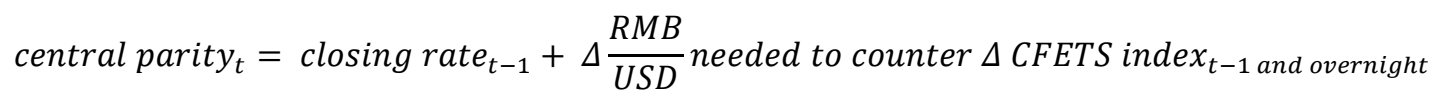

A technical modification was made to the formula a year later, in February 2017. Regarding the second part of the formula, banks were to offset cross-rate developments that took place only overnight, instead of developments during the previous day and overnight as they were previously instructed to do. This was to avoid "double counting" in the sense that the previous days movements were already being reflected in today's formula through their impact on the first part of the formula: the previous day's close. 


\section{Stability against the CFETS basket of currencies (mid-2016 to end-2017)}

Pressure on the RMB subsided in early 2017. Capital outflows abated in early 2017, partly due to CFMs, which reverted outbound direct investment back to pre-surge levels, and a pickup in external borrowing, and partly due to the global economic recovery, improved growth outlook for China, and a weaker U.S. dollar. FX intervention tapered off in early 2017 and reserves began to increase in February 2017 (partly due to valuation effects from a weaker dollar).
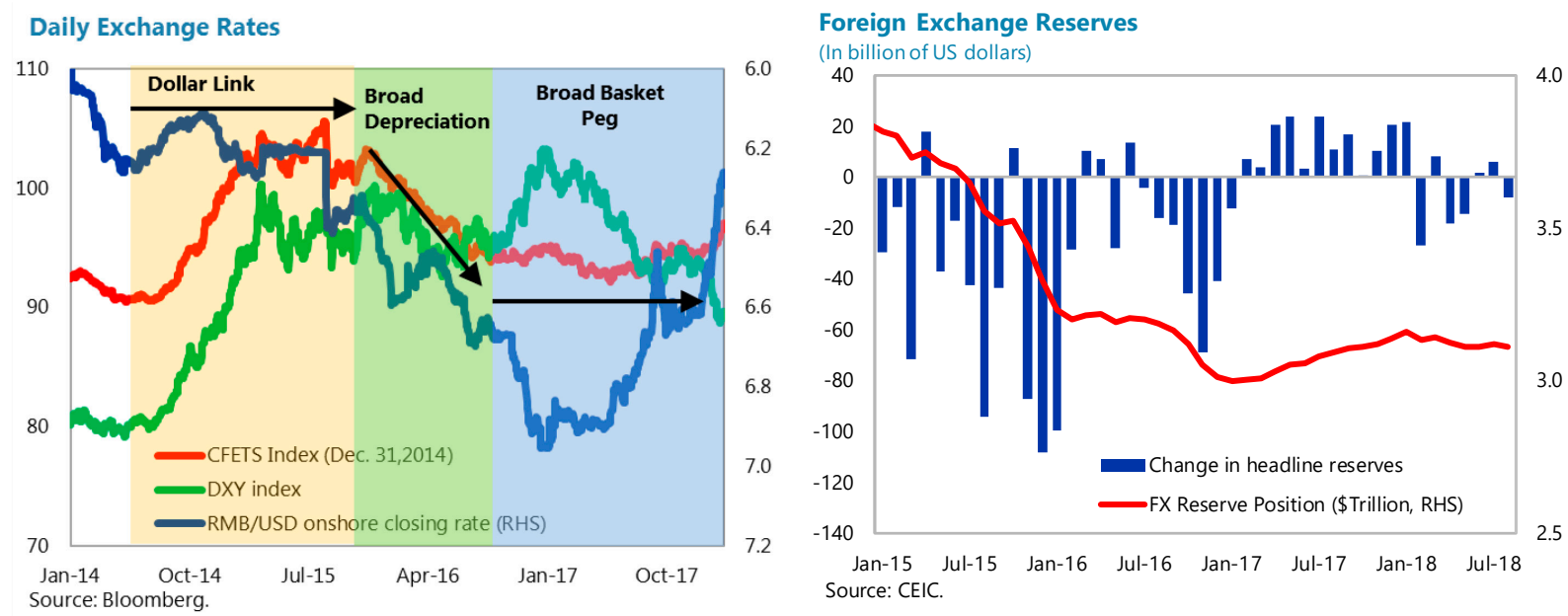

The RMB was been broadly stable against the CFETS basket from mid-2016 to end-2017, aided by the FX intervention and CFMs, as well as greater clarity from PBC guidance on the central parity mechanism. After depreciating against the CFETS basket by 10 percent from mid-2015 to mid-2016, the RMB was broadly stable against the basket until the end of 2017 . With the publication of the CFETS index and the new central parity quoting formula in place, China appeared to have finally made the transition to a de facto adjustable basket peg, as was indicated back in the 2005 reform announcement. Clark (2017) investigates the drivers of daily changes in the exchange value of the renminbi since early 2016, when the new central parity mechanism was formalized and understood. His findings suggest that, while the central parity rate has itself become quite predictable and responsive to market forces, the central parity rate does not consistently guide changes in the RMB/USD rate during the trading day. He finds that FX intervention to dampen volatility during the trading day has a greater impact on exchange rate movements than the central parity mechanism.

In a further attempt to guide the market toward stability, a 'counter-cyclical' factor was added to the central parity quoting mechanism in May 2017. On May 26, 2017, an announcement indicated the CFETS had adjusted its guidance to market-making banks on their central parity quotes. The banks were requested to include a "counter-cyclical adjustment factor" $(\mathrm{CCAF})$ in their quotes, with the objective of reducing "irrational" depreciation expectations and "pro-cyclical" herding behavior. The adjustment factor was not defined, with each bank calculating it using its own parameters to reflect its assessment of economic fundamentals. Many market participants viewed the CCAF as a tool used by the authorities to lean against changes in the RMB/USD during the previous day. Indeed, pass-through from the previous day's 
$\mathrm{RMB} / \mathrm{USD}$ closing rate to the current day's central parity rate declined after the introduction of the CCAF (Clark 2017).

USD/CNY: Central parity and previous close

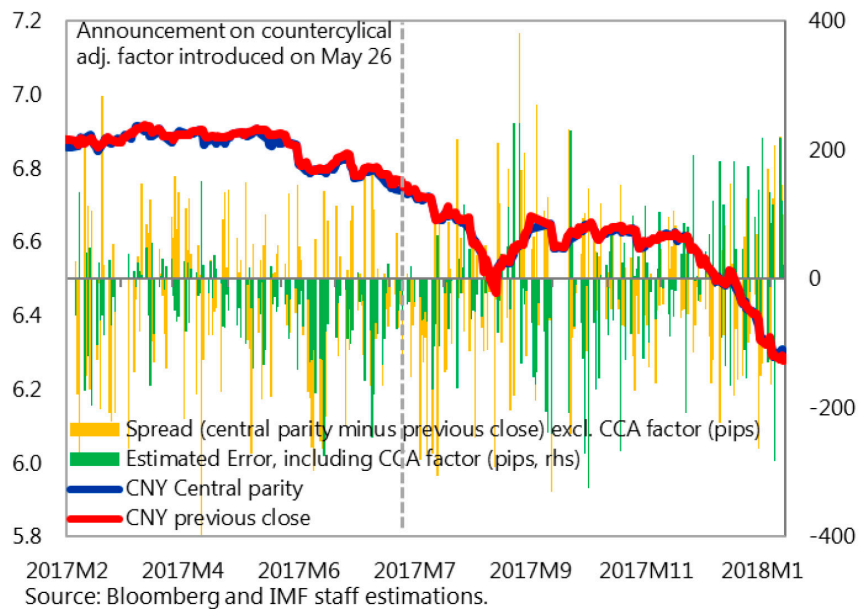

Monthly Average of Estimated Daily Error, including CCAF

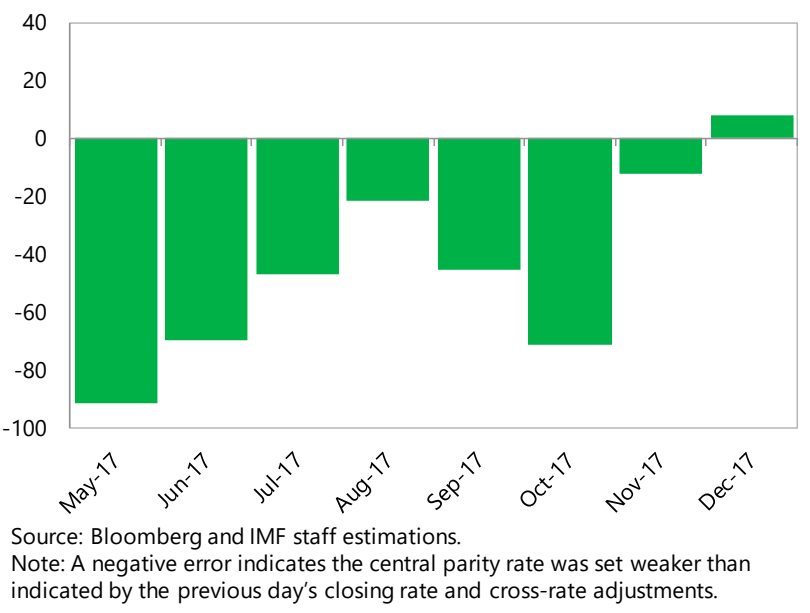

The countercyclical factor was then set to neutral in early 2018. With reduced pressures on capital flows and the exchange rate, the CCAF was set to "neutral" in January 2018. It was not dropped, however, and market expectations were that the CCAF would be reactivated in case of future "irrational" FX market behavior that could lead to exchange rate overshooting. Indeed, the CCAF was re-activated in August 2018, amid renewed depreciation pressure on the RMB (see next section).

\section{The current regime: Increasing moves towards flexibility}

China continued progress towards a floating exchange rate in the first half of 2018. Amid broad U.S. dollar strength, pressure on the RMB and other emerging market currencies resumed in April 2018. Depreciation pressure on the RMB intensified in mid-June, due to rising trade tensions and initial signs of slowdown in the economy. The RMB/USD rate depreciated by 2.5 from late April to mid-June, and a further 7.5 percent through mid-August, while the RMB depreciated by 1 percent against the CFETS basket until mid-June, and then a further 5.5 percent until mid-August. There was guidance from the PBC in early July suggesting the RMB would be basically stable, ${ }^{12}$ but no sign of significant intervention using FX reserves. The pace of change of the RMB - via both the U.S. dollar and the CFETS basket - was quicker than during any previous period. The episode was also unlike previous episodes of relatively sharp depreciation, in that significant capital outflows did not materialize in summer of 2018.

Before stepping in to counter depreciation pressures on the RMB. Actual measures to stabilize the RMB appear to have come in early August, when the PBC reinstituted the reserve

\footnotetext{
${ }^{12} \mathrm{http}: / / \mathrm{www} . x i n h u a n e t . c o m / e n g l i s h / 2018-07 / 03 / \mathrm{c}$ _137298801.htm
} 
requirement of 20 percent for banks' FX forwards transactions, encouraged banks to avoid "herd behavior", and re-activated the counter-cyclical factor in the central parity quotes. The RMB appreciated versus the U.S. dollar and CFETS basket somewhat after mid-August and then stabilized. While there were limited indications of direct intervention using reserves, it is difficult to gauge whether there had been indirect intervention.

\section{Compared to 2005, when China initiated the reform of its exchange rate regime, the RMB is more flexible with respect to the U.S. dollar and is now linked to the CFETS basket of currencies. This near-term basket link allows China to manage competitiveness relative to a greater number of trading partners, rather than just the U.S. The RMB/USD rate continues to trade in a narrow range on a daily basis, however, and, while the flexibility of the renminbi has increased, particularly since the beginning of 2018, it still exhibits less volatility than other floating currencies.}

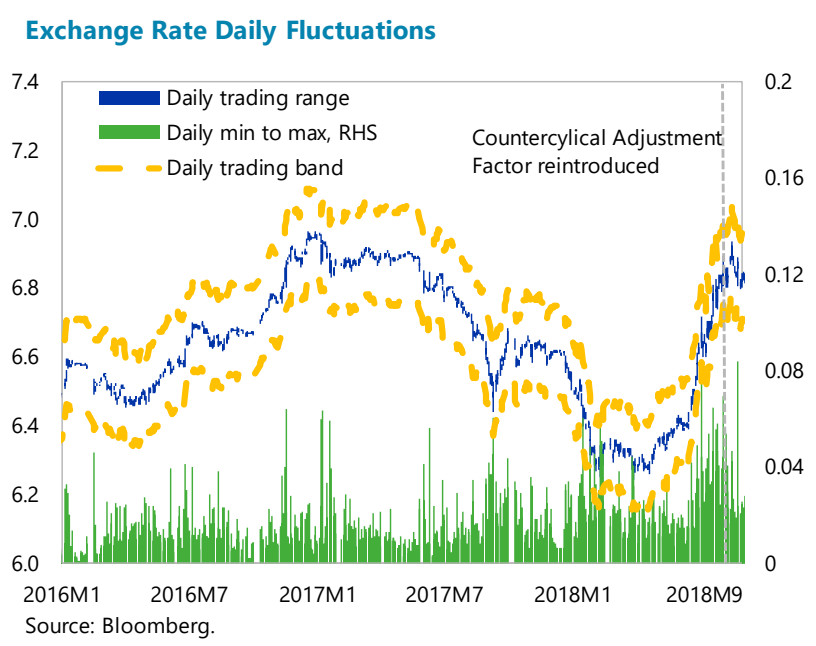

The exchange rate, while still managed in the short-run, has been allowed to adjust in response to market forces in the longer run. $\mathrm{PBC}$ statements have emphasized stability of the RMB in the short-term, while maintaining that the currency is market-determined in the longer run. A key question is whether the tension between tight shortterm control and desired longerrun flexibility is sustainable or creates increased risk of disruptive adjustment; and how to progressively shift the balance toward the stated goal of greater short-term flexibility over time.

China's exchange rate in 2017 is considered to be broadly in line with fundamentals. The IMF's 2018 External Sector

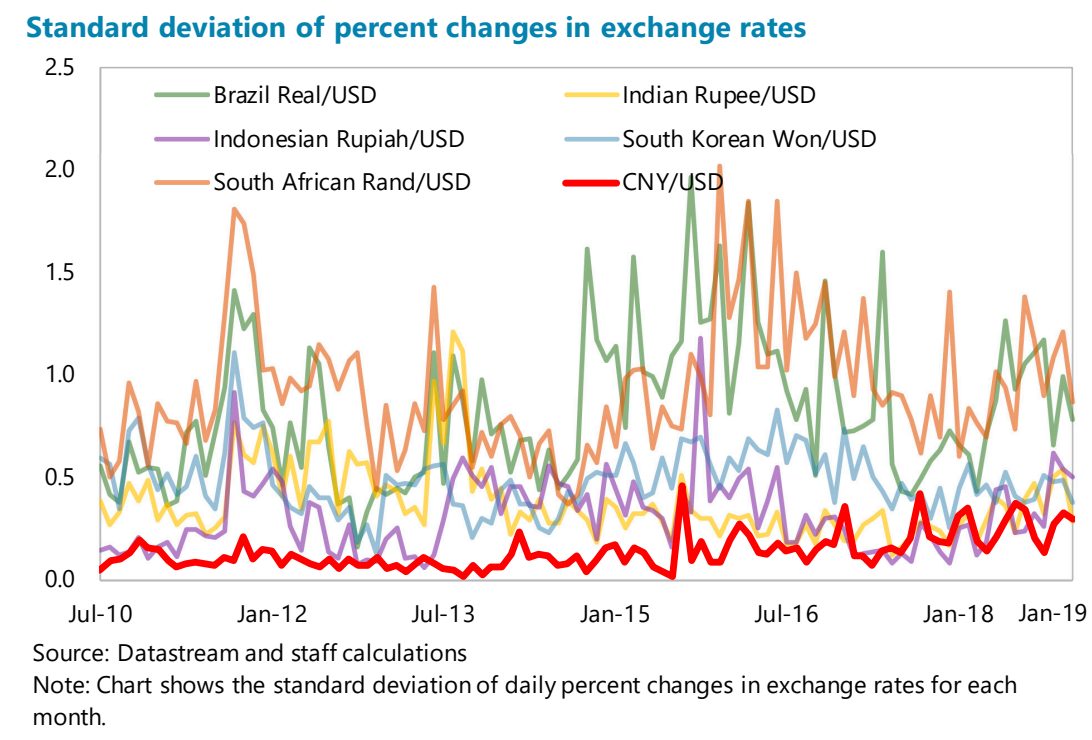

Report assesses the RMB in 2017 to be broadly line with fundamentals and desirable policies. FX reserves rose by US $\$ 129$ billion in 2017 , after declining by US $\$ 833$ in the previous two years, and are considered to be more than adequate to allow a continued gradual transition to a 
floating exchange rate. Reserves stood at 97 percent of the IMF's composite Assessing Reserve Adequacy metric unadjusted for CFMs; and at 157 percent of the metric adjusted for CFMs.

Internationalization of the RMB. China has been promoting the use of the RMB overseas. An offshore RMB market was established in Hong Kong SAR in 2010, and other offshore centers have developed in several countries. In 2015, the RMB was included in the IMF's special drawing rights (SDR) basket. As a precursor to inclusion in the SDR basket, financial market liberalization measures were instituted, including relaxing interest rate controls and permitting full participation by foreign central banks and sovereign wealth funds in the domestic bond market.

\section{Policy ISSUES}

\section{A. What should China's exchange rate regime be in the medium to longer-term?}

The Chinese economy will need a market-determined, flexible exchange rate to: (i) act as a shock absorber against external shocks, (ii) maintain the PBC's ability to influence domestic economic conditions via monetary policy, and (iii) continue progress made on the rebalancing of external demand (see Zhang 2016). As the capital account becomes more porous, and opens in the longer-term, the absence of a flexible exchange rate would lead to amplified economic cycles as capital flows inwards when domestic interest rates increase, and vice versa. Thus, the lack of a flexible exchange rate impedes the transition to a market-based monetary policy where interest rates affect credit allocation. ${ }^{13}$

\section{Although the $\mathrm{PBC}$ sees constraints to more flexibility in the short term, it has the long term objective of a flexible renminbi. As stated by PBC Governor Yi Gang: ${ }^{14}$}

"Exchange rates can serve as "automatic stabilizers" for the macroeconomy, and the orderly advancement of market reform of the renminbi exchange rate formation mechanism and enhancement of exchange rate flexibility will effectively increase the resilience of our economic and financial system to respond to external shocks. The PBC will continue to deepen reform of the renminbi exchange rate formation mechanism, perfect the managed floating exchange rate regime based on market supply and demand and adjusted with reference to a basket of currencies, strengthen market determination of exchange rates, enhance the flexibility of the renminbi exchange rate, and maintain the stable position of the renminbi exchange rate in the global monetary system."

\footnotetext{
${ }^{13}$ Ouyang and Rajan (2005) find a strong link between monetary conditions in China and the United States and, while CFMs limit Chinese integration with foreign markets, recent studies (e.g. Ma and McCauley 2013) find that financial integration is increasing, thereby limiting the autonomy of Chinese monetary policy if the exchange rate does not become more flexible.

${ }^{14}$ Yi Gang, 2018, "Monetary Policy Retrospective and Outlook”, China Finance, 2018, Issue 3. Written while Deputy Governor of the PBC.
} 


\section{B. Fear of floating - Is China different?}

Typical reasons for fear of floating do not seem to currently apply for China. The literature has identified several reasons why countries have been reluctant to allow their currencies to float. These include (i) a fear of misalignment, and in particular of appreciation of the domestic currency, and an adverse impact on the external balance; and (ii) a high share of foreign currency liabilities (Calvo and Reinhart 2002). While these factors have some relevance, the case of China is for the most part unique.

(i) Misalignment. Concerns about competitiveness have played a role in exchange rate policy over the course of China's economic development. At the current stage, however, the exchange rate does not seem managed to advantage exporters and the real effective exchange rate is estimated to the be broadly in line with fundamentals. There are still concerns, however, that the exchange rate could become misaligned without management.

(ii) Foreign currency liabilities. China's aggregate foreign exchange exposures appear to be contained. While the corporate sector is highly leveraged, with debt at about 160 percent of GDP, only 6 percentage points of this is denominated in foreign currencies. Banks also have relatively limited FX exposures. Banks are subject to limits on their FX positions and net exposures are small, as they also hold FX assets. ${ }^{15}$ The FX exposures of non-bank financial institutions are difficult to assess due to lack of data, but generally appear to be small. The share of FX denominated government liabilities is quite small, while the share of FX denominated assets is very high.

\section{A key constraint to greater flexibility specific to China stems from its large pool of} renminbi savings seeking diversification, and herding behavior that creates a vulnerability to large depreciation events. In China, a key concern of policymakers comes from factors that could combine to lead to a large and disorderly depreciation of the exchange rate, with indirect negative effects on financial stability.

- First, a large pool of RMB-denominated savings is held by residents, with M2 at around 200 percent of GDP, and there are insufficient domestic assets in which to invest. Chinese residents' demand for foreign assets is suppressed by CFMs and even a small fraction of households switching to foreign assets could lead to sizeable capital outflows. ${ }^{16}$ See Bayoumi and Ohnsorge (2013) who find, among others, that capital account liberalization in China

\footnotetext{
${ }^{15}$ For the four largest banks, 11 percent of liabilities were in FX in 2015, with an offsetting amount of FX assets. For individual banks, gross FX exposure ranged from 26 percent of total liabilities for Bank of China to 5 percent for the Agricultural Bank of China.

${ }^{16}$ Chinese investors exhibit a high degree of home bias but this is likely to decline somewhat over time. Chinese domestic retail investors, for example, own around 80 percent of tradable shares by market capitalization. This is concentrated among wealthy investors, however, who can easily reallocate assets, raising the possibility of large asset outflows. Coeurdacier and Rey (2013) show that home bias has declined in developed economies since the late 1980s but, even in these economies that have long had open capital accounts, it remains higher than predicted by theory.
} 
may lead to net portfolio outflows. Furthermore, household demand for foreign exchange continues to grow.

- Second, residents exhibit herding behavior in response to shocks. Herding behavior is present in most financial markets but, against a background of a pegged exchange rate until 2005, followed by a gradual appreciation versus the dollar over the following decade, Chinese residents are not used to regular two-way movements in the exchange rate and thus their expectations are more sensitive to signals of change. Exporters, for example, decreased the amount of foreign currency income they convert to renminbi following the August 2015 episode and have not raised the conversion share back to their previous pattern.

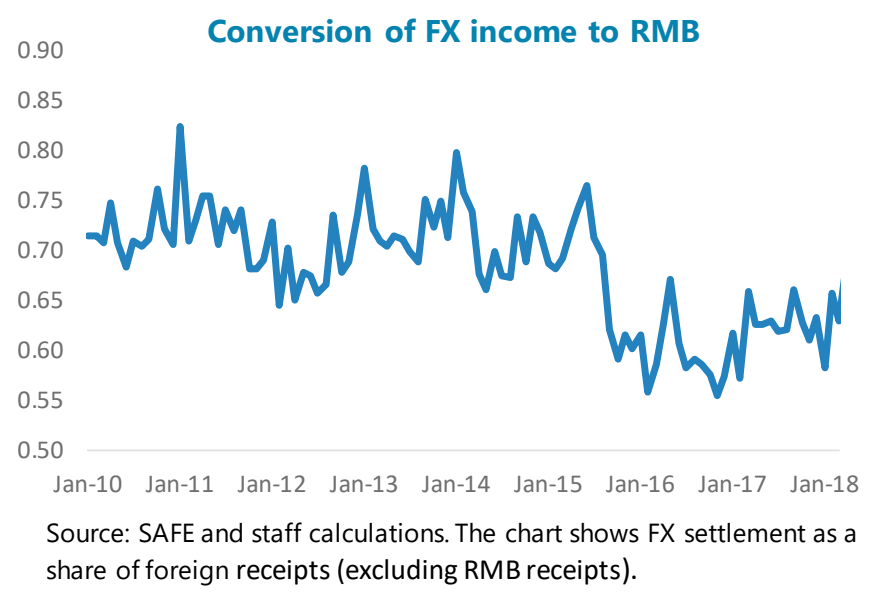

These factors combine to increase the sensitivity of residents' outward capital flows to the RMB exchange rate. If households and corporates move money abroad suddenly and are reluctant to lend or invest in renminbi, this could trigger funding shocks for banks and nonbanks, and possibly fire sales and large-scale redemptions of short-term investments, such as wealth management products. This could lead to credit risk being abruptly repriced and restricted, adding to corporate stress. The equity market would also likely come under strong downward pressure.

\section{As a systemic country, China also expresses concerns about potential external spillovers} from sudden renminbi movements and associated financial market turmoil in the region. Using an approach that groups countries into currency blocs based on currency co-movements, Tovar and Mohd Nor (2018) find that the renminbi is one of three currencies, along with the U.S. dollar and Euro, that dominate global exchange rate movements. The renminbi now influences the exchange rates of countries representing about 30 percent of global GDP, primarily from its influence on BRICS countries. The authors' do not find evidence suggesting that the RMB is the dominant currency in Asia, however, with the U.S. dollar still playing a dominant role.

Furthermore, while the RMB's share in worldwide payments has increased over time, it is still low, ranking seventh with a share of about 1.5 percent in 2017. Studying the period since August 2015, McCauley and Shu (2018) find that co-movement between the RMB and other currencies depends on the extent of management of the RMB. 


\section{Policies supporting flexibility}

Supporting conditions for a smooth transition. IMF (2004a and 2004b) laid out a framework for achieving a successful and smooth transition from a largely fixed to floating exchange rate regime. In addition to sound macro policy, the ingredients needed for success include:

1) Developing a liquid and deep FX market;

2) Building the capacity of market participants to manage exchange rate risk and of the supervisory authorities to monitor and regulate exchange rate exposure;

3) Establishing an appropriate alternative nominal anchor in the context of the new monetary policy framework and developing supporting markets; and

4) Formulating coherent intervention policies consistent with the new monetary policy framework.

The benefits of progress in these areas and greater exchange rate flexibility are mutually reinforcing: progress on these conditions requires greater exchange rate flexibility and progress on implementing these conditions will in turn set the stage for even greater exchange rate flexibility in the future. This section discusses China's progress on each of these supporting conditions.

\section{Developing a liquid and deep FX market}

\section{Background.}

The onshore FX market has been active since the mid-1990s and a number of measures have been taken since 2005 to improve its efficiency. The PBC set up an interbank currency market, the CFETS, in April 1994. Participation in the FX market has grown from only a small set of state-owned banks at the beginning to now include the big commercial banks, their local and foreign branches, other domestic banks, subsidiaries of foreign banks, and subsidiary financial companies of big state-owned enterprises (SOEs) and big private companies. ${ }^{17}$ The CFETS trading system has expanded from initially focusing on the RMB/USD rate to trading in twenty-four currencies, but over 95 percent of daily trading volume still takes place in the $\mathrm{CNY/USD}$ pair. A number of measures have been taken since 2005 to improve the efficiency of the onshore $\mathrm{CNY}$ market:

- A market-making system was introduced on the CFETS in 2005, whereby a group of participants are designated market makers, providing liquidity by being prepared to buy and sell currencies throughout the trading day. Of the 632 current members of the spot market, 32 banks, both domestic and foreign, are designated as market makers.

\footnotetext{
${ }^{17}$ As of September 2018, there are 649 members in the spot market, 192 members in the forward and swap market, and 111 members in the options market.
} 
- FX forwards, swaps, and options were introduced in the interbank FX market in 2005, 2006, and 2011 respectively.

- Limits on selling-buying spreads for banks have been loosened (from 1 to 2 percent of central parity for the RMB/USD rate in 2012, removed completely in the OTC market in 2014).

- Trading hours were extended from 4:30pm to 11:30pm in 2016.

- Cash settlement, and thus netting, of FX forwards was allowed starting in 2018. Prior to this, forwards were settled on a physical basis, meaning the underlying currencies had to be delivered to the counterparties upon maturation.

\section{Despite these measures, liquidity and depth of China's onshore FX market remains relatively low compared to other countries with de jure floating currencies.}

- Liquidity. As more active markets tend to be more liquid, we look at turnover data from the 2016 BIS Triennial Central Bank Survey, which indicates that China's average daily FX turnover as a share of exports and imports is just $13 / 4$ percent. ${ }^{18}$

- Depth. The volume of transactions at a range of rates, which can be used to gauge the depth of the market, is also limited compared to other countries (see Annex I for volume by price charts for the $\mathrm{CNY}$ and the other BRIICS currencies). ${ }^{19}$

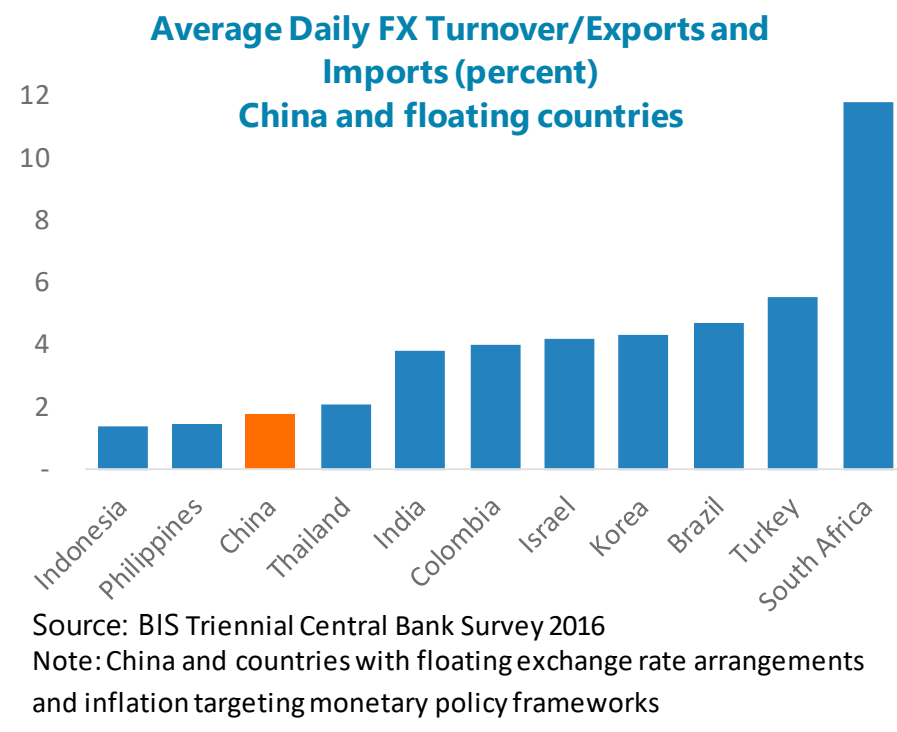

\footnotetext{
${ }^{18}$ Renminbi liquidity is higher offshore, however. The renminbi is unique among all major emerging market currencies in that a large share of its turnover takes place in offshore markets (Ehlers and Packer 2013).

${ }^{19}$ The liquidity and depth of a market can typically also be assessed by looking at the bid-ask spreads of transactions. This measure cannot be used, however, when the exchange rates under consideration are not predominantly market-determined and thus do not reflect liquidity risk.
} 
The renminbi trades in a small range on a daily basis, compared to other de jure floating countries. Furthermore, the market is concentrated, with trading dominated by the large, stateowned banks and, while there are several foreign bank participants, their share in trading volume is low.

\section{A lack of sufficient two-way} exchange rate movement and diversity of investors impedes market development. Carefully managing the exchange rate reduces

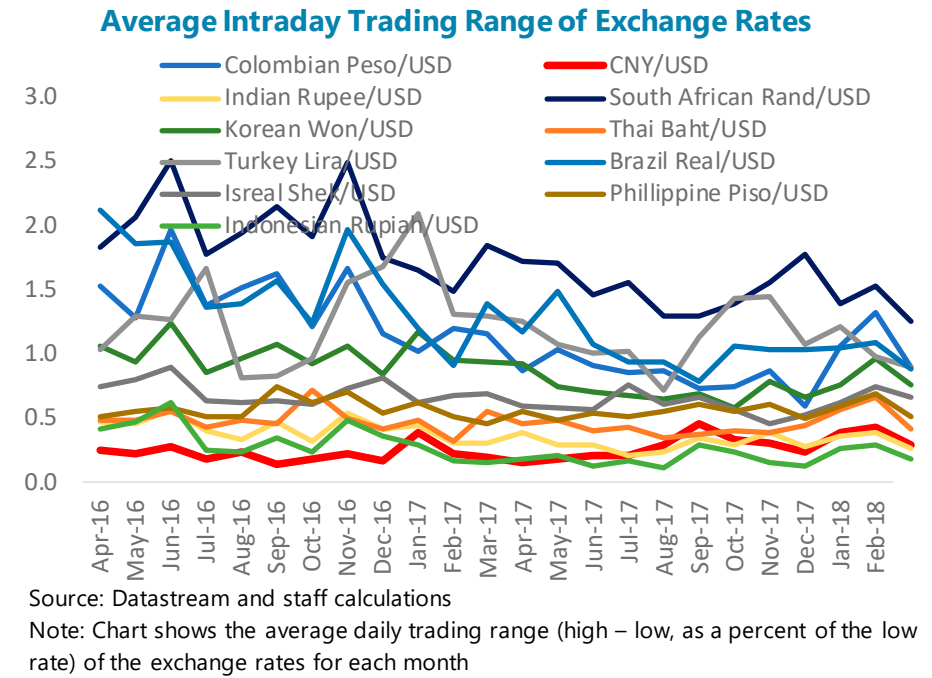
the need for non-central bank participants to trade and gain experience in price formation and FX risk management. The lack of participation by non-bank institutions in the onshore FX market exacerbates the herding effect, leading to increased risk for banks and ultimately higher costs for retail investors. Further capital account liberalization should be carefully sequenced with the necessary supporting reforms, including an effective monetary policy framework, sound financial system, and exchange rate flexibility. In the longer-term, as CFMs are loosened, depth and price discovery in the onshore FX market, along with other asset markets, would improve.

\section{Policy Recommendations.}

- Allowing sufficient exchange rate flexibility is a key step to improve efficiency of the market. Even relatively small fluctuations in the exchange rate create incentives for market participants to gather information, form views, and manage FX risks.

- It is essential to create a sense of two-way risk in the exchange rate - that is that the exchange rate can appreciate or depreciate - to avoid one-directional sentiment and deter speculative capital inflows.

- Encouraging various types of institutions to participate in the interbank FX market would improve the efficiency and depth of the market.

\section{Capacity to regulate, monitor, and manage exchange rate risks}

\section{Background.}

\section{Instruments that market participants can use to hedge exchange rate risk have been} introduced since 2005, and their use has subsequently increased. The share of FX derivatives transactions in average daily FX turnover in China has gone from 10 percent in 2007 to 60 percent in 2016. These instruments can be used for both hedging and speculative activities, however, and it is difficult to measure actual hedging activities. However, banks are required to 
keep documentation of the underlying current-account related transactions for spot FX trades, in line with the "principle of actual demand," and the underlying exposure for derivatives trades.

However, use of hedging instruments remains low and the pricing of derivatives with medium and longer maturities is challenging. Focusing on the use of forwards and swaps with a maturity of one year or less as a proxy for hedging activities, ${ }^{20}$ it appears that Chinese firms are below the cross-country average in using hedging instruments. ${ }^{21}$

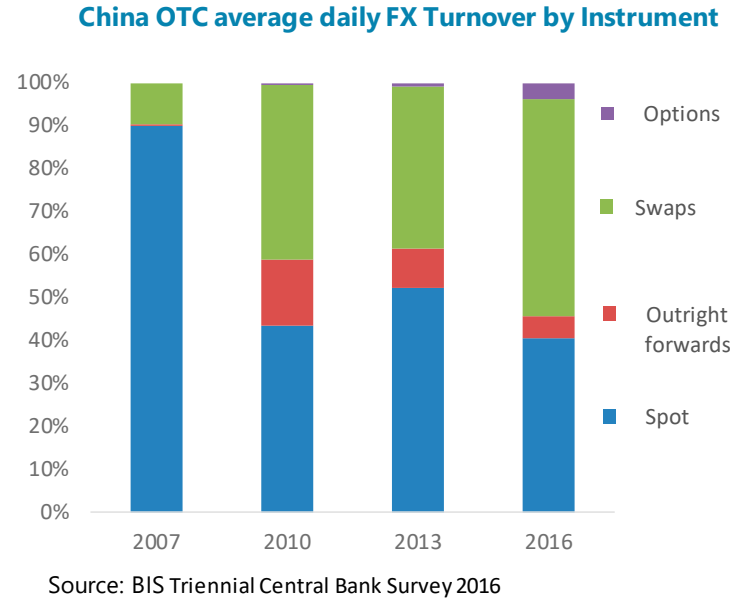

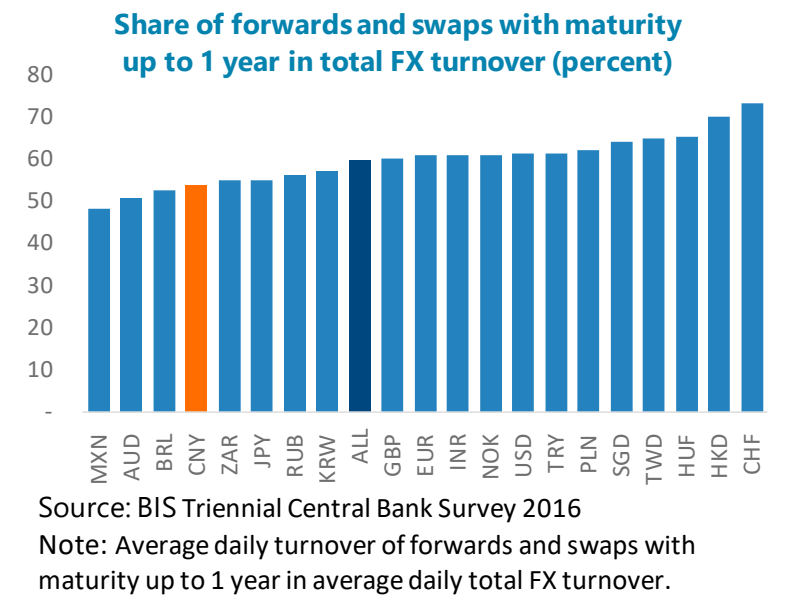

Share of forwards and swaps with maturity

Moreover, low liquidity in the medium and long end of the yield curve, as well as thin overall secondary market activity beyond the 10-year maturity, limit the reference function of government bonds for other instruments (Chen et al, 2019).

Several regulations and tools are in place to monitor FX risks. Banks' FX exposures are reported to supervisors on a quarterly basis and there is a limit on banks' net open FX position. ${ }^{22}$ Also, when banks are active in FX transactions, the monitoring of liquidity indicators is strengthened, with consideration given to liquidity risk in each significant currency.

\section{Policy recommendations.}

- To set the stage for increased exchange rate flexibility, market participants need to be educated about FX risks and encouraged to hedge.

\footnotetext{
${ }^{20}$ Surveys of U.S. managers indicate that around 80 percent of hedging is done at a maturity of one year or less.

${ }^{21}$ In mid-February 2018, SAFE allowed for the cash settlement, and thus netting, of FX forwards. Prior to this, forwards were settled on a physical basis, meaning the underlying currencies had to be delivered to the counterparties upon maturation. As such, prior to 2018, the BIS data may overstate the share of non-spot transactions in overall FX turnover in China compared to other countries.

${ }^{22}$ The limit on a bank's net FX open position was linked to its FX loan-to-deposit ratio prior to 2015, when it was delinked.
} 
- Considerations to guide the effective use of derivatives include (IMF 2004a):

(i) close monitoring of the use of instruments to prevent their pushing a normally sustainable situation over the edge through sizeable leveraged bets;

(ii) the standardization of derivative products traded among banks, the presence of accounting standards for fair valuation, and a reliable legal system for contract enforcement; and

(iii)the central bank promoting market transparency and, with other regulators, high reporting standards.

- Further developing the government bond market will improve the benchmark for credit pricing that is needed for proper pricing of hedging instruments.

\section{An appropriate alternative nominal anchor and developing supporting markets}

\section{Background.}

The PBC has multiple objectives and lacks operational authority. The objectives of the PBC, mandated by the Chinese government, are to maintain price stability, boost economic growth, promote employment, and broadly maintain the balance of payments. The PBC is also required to promote reform and opening up as well as financial market development. Furthermore, fiscal dominance (large broadly-measured deficits and resulting pressures for credit expansion) impinges on the efficacy of monetary policy. While many central banks have the multiple objectives of price stability, employment, and financial stability, a framework that focuses primarily on price stability strengthens the communication and transmission of monetary policy. From the perspective of moving to exchange rate flexibility, a framework and nominal policy anchor that focuses on the domestic economy is necessary, and the objective of having a balance of international payments inhibits the transition by keeping the focus on the exchange rate.

China's domestic monetary policy framework has become more market-based and increasingly relies on an interest rate corridor, though the development of the 7-day repo rate as the policy interest rate is still in early stages. Controls on bank lending and deposit rates have been abolished and the $\mathrm{PBC}$ has mentioned that it is using the 7-day reverse repo rate to send policy signals, with the 7-day interbank repo rate for depository institutions as the operating target. In addition, the $\mathrm{PBC}$ has de-emphasized money growth and did not set an M2 target for 2018. However, the official policy rates remain the benchmark lending and deposit rates (although they are no longer binding) and markets still focus on the exchange rate and international reserves as indications of the PBC's policy intentions. The majority of interest rate increases in 2017 came immediately after hikes by the US Federal Reserve, suggesting a concern about capital flows and focus on the balance of payments objective.

A lack of transparency and clarity of communication causes uncertainty and has allowed confusion in the markets. As demonstrated by the August 2015 episode, brief or unclear 
announcements can cause a sudden shift in expectations and lead to market turbulence.

Expectations are particularly sensitive to shifts since a lack of regular communication and guidance by the PBC leads to stagnant information and expectations formation. In addition, there appears to be a tension in the often stated goals of enhancing flexibility and market determination of the exchange rate and ensuring the RMB remains basically stable. As stated in a recent monetary policy report: ${ }^{23}$

"The Bank will continue to pursue the reform of the mechanism for RMB exchange rate formation and improve the managed floating of exchange rates, on the basis of market supply and demand, with a basket of currencies as its reference. It will allow the market to play a greater role in determining exchange rates and enhance the two-way floating flexibility of the RMB exchange rates, which will be kept relatively stable and at a reasonable and balanced level. ..." ${ }^{24}$

\section{Policy Recommendations.}

- The PBC should be granted operational independence and develop an explicit policy rate, while the State Council sets the overall goals for monetary policy (but not specific interest rates or monetary targets). The $\mathrm{PBC}$ should guide the short-term interbank rate in the clearest manner possible, and let longer-term rates be market-determined, reflecting expectations of the central bank's future policy rates and future inflation, among other factors. The clearer the policy framework, the easier it will be for the market to establish a yield curve. The interest-rate based framework would be strengthened by: (1) formally acknowledging the framework, (2) dropping the publication of benchmark lending rates, (3) gradually reducing the distortionary high reserve requirements (offset as needed by openmarket operations), (4) basing pricing and access to the PBC's lending facilities on clearly defined collateral rules and not supervisory criteria, and (5) aligning lending instruments more closely to the PBC's monetary policy objectives.

- Improved and regular communication. Considerable scope remains to: (1) clarify the objectives of monetary policy and how the policy instruments relate to those objectives, (2) publish macroeconomic forecasts regularly, and provide information about the framework and models used, and (3) publish policy communications simultaneously in English, given the growing global integration of Chinese financial markets. Regular press conferences and a regular schedule of MPC meetings at which most policy interest rate decisions are made would be helpful (see McMahon et al 2018).

\footnotetext{
${ }^{23}$ People's Bank of China (2017), Monetary Policy Report, Fourth Quarter 2017, Chapter 5, Section II, “Main Policy Objectives for the Next Stage".

${ }^{24}$ The term "reasonable and balanced" has in fact been suggested to mean the level of the exchange rate that is consistent with equilibrium in the balance of payments and cross-border capital flows. That is, to indicate that it is only at the equilibrium level where the exchange rate can and will be relatively stable. This is not clear to market participants, however, and expanding on this would help market participants.
} 


\section{Allowing a greater role for market forces}

\section{Background.}

Multiple tools to manage the exchange rate. The current exchange rate regime consists of:

- the central parity rate, formed and announced each morning before the beginning of the trading day,

- the daily band of $+/-2$ percent around the central parity rate, within which trades can take place, and

- FX intervention to help manage the exchange rate.

The PBC additionally uses changes in CFMs to help manage the exchange rate. As discussed in section II, the central parity is often set at a value that offsets some of the previous day's exchange rate movements, particularly when the countercyclical adjustment factor is in use.

\section{When needed to limit excessive volatility, using only direct FX intervention and explicit PBC communication to affect the exchange rate is better than guiding it through the} central parity rate or other forms of moral suasion. First, intervention is more effective. Clark (2017) found that FX intervention to dampen volatility during the trading day has a greater impact on exchange rate movements than the central parity mechanism. This is not surprising considering the central parity rate can signal an intention to limit movement in a particular direction at the start of the trading day but, if there is enough pressure in that direction, FX intervention will be necessary in any case to limit it. Second, an opaque central parity formation puts an undue amount of focus on the central parity itself, which can lead to market participants trying to interpret policy intentions through the rate instead of actual statements of policy by the PBC. Finally, using only one instrument to manage the exchange rate is simpler and would facilitate the move towards less active management of the exchange rate in the future. PBC communication to give context to exchange rate moves and provide guidance on economic factors shaping its future path is also important.

\section{Policy Recommendations.}

- Central parity formation should be mechanical and transparent, and the quote formula should be consistent over time.

- FX intervention should be limited to minimizing excessive volatility, and sustained one-way intervention should be avoided.

- Publishing information on the PBC's FX intervention would improve market understanding and strengthen the credibility of the policy framework.

- CFMs should be consistently and transparently enforced and clearly communicated, and they should not be used to actively manage the capital flow cycle and substitute for exchange rate flexibility. 
- Providing guidance to the market on economic trends and their implications for the real exchange rate in the longer term would also help the market form expectations.

\section{Conclusion}

China's exchange rate regime has undergone gradual reform since the move away from a fixed exchange rate in 2005. Regular steps towards greater exchange rate flexibility have been taken, and have been accompanied by moves to increase participation and improve efficiency in the FX market. As a result, the exchange rate has become more flexible over time, but it is still carefully managed. Moreover, depth and liquidity in the FX market is relatively low compared to other countries with de jure floating currencies.

At this stage, allowing for greater two-way flexibility of the exchange rate is a critical step that will build on the progress already made. Allowing a greater role for market forces in the current regime - by making central parity formation for the daily trading band mechanical and transparent, limiting the use of FX intervention to preventing excessive volatility, and not modulating CFMs to help manage the exchange rate - is important. These steps should be complemented by further steps to develop the FX market, improve FX risk management, and to develop an alternate monetary policy anchor by continuing to modernize the monetary policy framework. 


\section{REFERENCES}

Bayoumi, Tamim and Franziska Ohnsorge, 2013, "Do Inflows or Outflows Dominate? Global Implications of Capital Account Liberalization in China," IMF Working Paper WP/13/189, August 2013.

Calvo, Guillermo A. and Carmen M. Reinhart, 2002, "Fear of Floating," The Quarterly Journal of Economics, Vol. 117, No. 2 (May, 2002), pp. 379-408

Chen, Sally., Kevin Chow, ZHANG Longmei, Thomas Harjes and Nathan Porter, 2019, "Sovereign Bonds: What the Yield Curve Tells Us?" in Alfred Schipke, Markus Rodlauer, and ZHANG Longmei, eds., The Future of China's Bond Market, Washington, D.C. (IMF) 2019.

Clark, John, 2017, "China's Evolving Managed Float: An Exploration of the Roles of the Fix and Broad Dollar Movements in Explaining Daily Exchange Rate Changes," Federal Reserve Bank of New York Staff Report No. 828, November 2017

Nicolas Coeurdacier and Hélène Rey, 2013, "Home Bias in Open Economy Financial Macroeconomics” Journal of Economic Literature, Vol 51, No 1, March 2013, pp 63-115.

Eichengreen, Barry, 2005, "Is a Change in the Renminbi Exchange Rate in China's Interest?", Prepared for the Asian Economic Panel, Hong Kong, April 2004, Revised version dated March 2005.

Ehlers, Torsten and Frank Packer, 2013, "FX and derivatives markets in emerging economies and the internationalisation of their currencies," BIS Quarterly Review, December 2013

International Monetary Fund, 2004a, From Fixed to Float: Operational Aspects of Moving Toward Exchange Rate Flexibility (Washington). www.imf.org/external/NP/mfd/2004/eng/111904.htm

International Monetary Fund, 2004b, "IMF Executive Board Discusses 'Fixed to Float: Operational Aspects of Moving Toward Exchange Rate Flexibility'" (Washington). www.imf.org/external/np/sec/pn/2004/pn04141.htm

International Monetary Fund, 2007, Occasional Paper 256, "Moving to Greater Exchange Rate Flexibility, Operational Aspects Based on Lessons from Detailed Country Experience

International Monetary Fund, 2015, “2015 External Sector Report - Individual Economy Assessments," July 2015.

International Monetary Fund, 2017, “2017 External Sector Report - Individual Economy Assessments," July 2017.

Guonan Ma and Robert N McCauley, 2013, “Is China or India more financially open?” BIS Working Papers No 410. April 2013

McCauley, Robert N and Chang Shu, 2018, "Recent RMB policy and currency co-movements," BIS Working Papers No 727, Bank of International Settlements, June 2018 
McMahon, Michael, Alfred Schipke, and LI Xiang, 2018, "China’s Monetary Policy Communication: Impact, Frameworks, and Recommendations," IMF Working Paper, WP/18/244, November 2018

Obstfeld, Maurice, 2007, "The Renminbi's Dollar Peg at the Crossroads," Monetary and Economic Studies, Institute for Monetary and Economic Studies, Bank of Japan, Vol 25(S1), pp. 29-56.

Ouyang, Alice and Ramkishen Rajan, 2005, "Monetary Sterilization in China Since the 1990s: How Much and How Effective?," Centre for International Economic Studies Working Papers 2005-07, University of Adelaide, Centre for International Economic Studies.

Tovar, Camilo E. and Tania Mohd Nor, 2018, "Reserve Currency Blocs: A Changing International Monetary System?” IMF Working Paper WP/18/20, January 2018

ZHANG, Longmei, 2016, "Rebalancing in China-Progress and Prospects," IMF Working Paper WP/16/183, September 2016

Jiadan Jiang, David Kim, 2013, July 2013, Exchange rate pass-through to inflation in China, Economic Modelling, Vol 33, pp 900-912 
ANNEX I. BRICS CURRENCIES - VOLUME TRADEd BY PRICE

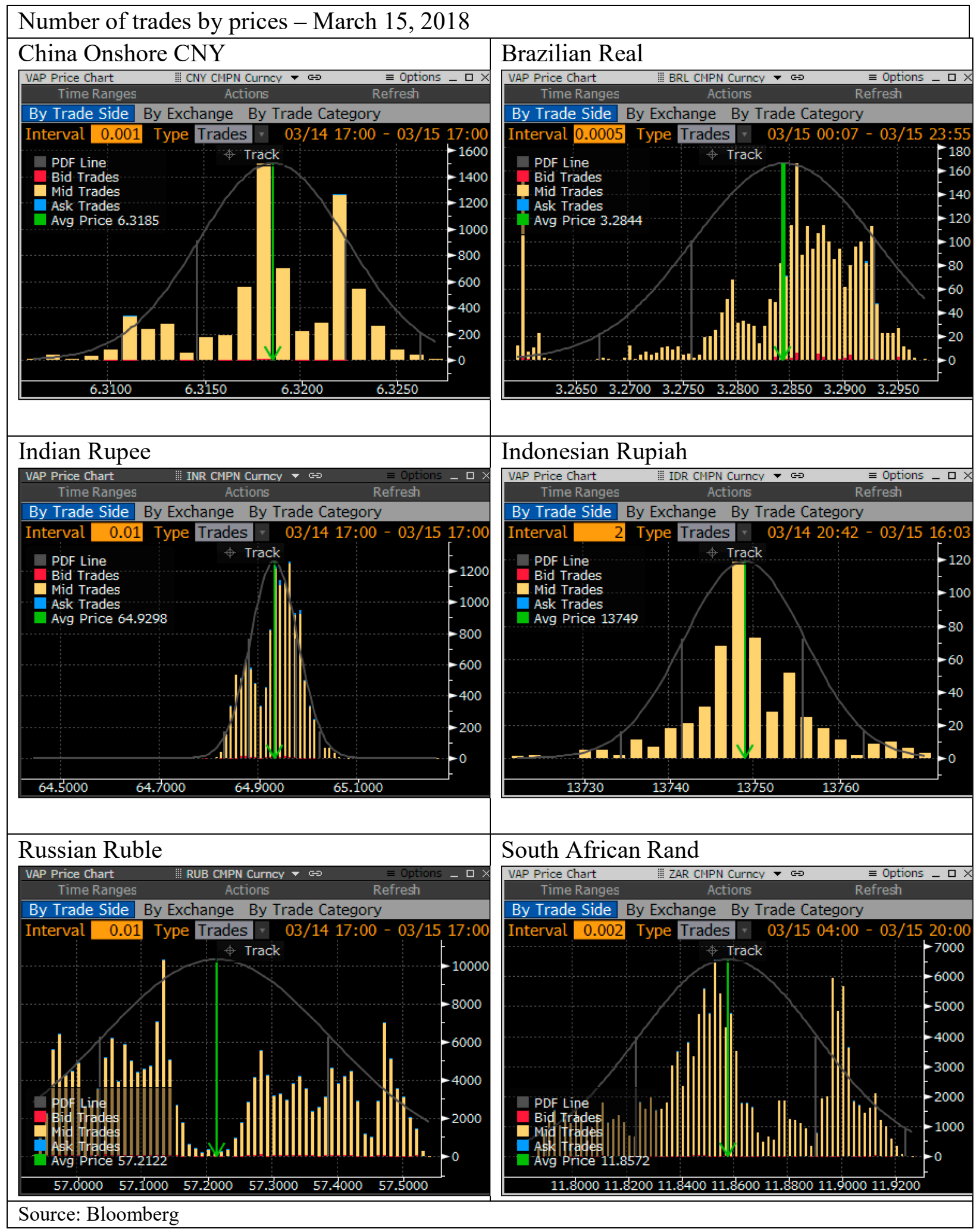




\section{ANNEX II. EXAMPLES FROM INTERNATIONAL EXPERIENCE}

\section{Countries have used various strategies for moving from fixed to flexible exchange rate}

regimes. ${ }^{25}$ Chile, Israel, Poland, and Russia are examples of countries that have had gradual and, for the most part, orderly transitions to free floating exchange rates. ${ }^{26}$ This section presents a brief summary of their experiences and the lessons that can be drawn from their transitions to greater exchange rate flexibility.

Motivation for greater flexibility. Greater flexibility in these countries was introduced when multiple monetary policy objectives became incompatible, with a growing emphasis on reducing inflation rather than on other goals such as competitiveness. The need for greater flexibility grew as countries opened capital accounts and received inflows that complicated monetary management. In Israel, the desire to encourage better risk management provided an additional motivation for moving to greater flexibility.

Process. The transitions generally proceeded by:

- The adoption of crawling pegs in the initial stages of transition, as a desire to strike a balance between the goals of reducing inflation and safeguarding competitiveness.

- Followed by more flexible exchange rates within pre-announced horizontal or crawling bands, to absorb the impact of inflows and let the authorities set interest rates at levels consistent with inflation targets, while reassuring markets that there could not be major exchange rate moves. Direct FX market intervention was used, usually near the edges of the band, to smooth exchange rate volatility.

- Followed by a gradual widening of bands, combined with a decrease in FX intervention, until the exchange rate was effectively floating freely. As countries moved closer to achieving freely floating exchange rates, formal policies of no intervention were also used.

Time table. The transition to a free float took about 15 years in Chile, 20 years in Israel (for a formal free float, with a de facto free float achieved in 12 years), 10 years in Poland, and 9 years in Russia. ${ }^{27}$ Importantly, though, the benefits of greater flexibility began at an early stage in the transition. Having several adjustments to the regime likely helped avoid disorderly episodes while giving the authorities time to put the most important supporting elements of a flexible regime into place.

\footnotetext{
${ }^{25}$ This section draws largely on International Monetary Fund (2007) "Moving to Greater Exchange Rate Flexibility, Operational Aspects Based on Lessons from Detailed Country Experience" for the experiences of Chile, Israel, and Poland and several editions of the IMF Annual Report on Exchange Arrangements and Exchange Restrictions for the Russian experience.

${ }^{26}$ Many countries, such as Brazil, Czech Republic, Thailand, and Uruguay, have moved quickly to floating exchange rate regimes under market pressure. In this section, we consider countries that have had gradual and smooth transitions.

${ }^{27}$ Except for Russia, this time period is from the starting point of a peg to single currency or basket, to a somewhat more flexible regime - a process that began 13 years ago in China, in July 2005.
} 


\section{Table: Summary of Country Experiences with Transition to Flexible Exchange Rate}

Regimes

\begin{tabular}{|c|c|c|c|c|}
\hline & Chile & Israel & Poland & Russia \\
\hline Pace of the exit & Gradual (1984-99) & Gradual (1985-2005) & Gradual (1990-2000) & Gradual (2005-2014) \\
\hline From which regime & $\begin{array}{l}\text { Crawling peg (Sep 1982) to } \\
\text { crawling band (Aug 1984) with } \\
\text { purchasing power parity } \\
\text { adjustments based on foreign } \\
\text { inflation (based on a basket of } \\
\text { currencies), lagged domestic } \\
\text { inflation, and productivity } \\
\text { adjustments; gradual widening } \\
\text { of the band }\end{array}$ & $\begin{array}{l}\text { Peg to horizontal band; } \\
\text { horizontal band to increasingly } \\
\text { wider crawling bands }\end{array}$ & $\begin{array}{l}\text { Single currency peg to a } \\
\text { basket peg; then to crawling } \\
\text { peg; then to crawling band, } \\
\text { with increasingly wider bands, } \\
\text { combined with declining rates } \\
\text { of crawl }\end{array}$ & $\begin{array}{l}\text { Managed float of dual- } \\
\text { currency basket to horizontal } \\
\text { band around basket; to } \\
\text { crawling band, with } \\
\text { increasingly wider bands, with } \\
\text { adjustments to crawl based on } \\
\text { cumulative amount of FX } \\
\text { intervention }\end{array}$ \\
\hline To which regime & Free float (Sep 1999) & $\begin{array}{l}\text { De facto free float (Jun 1997); } \\
\text { formal free float (Jun 2005) }\end{array}$ & Free float (Apr 2000) & Free float (Nov 2014) \\
\hline Duration of each stage & $\begin{array}{l}\text { Crawling peg (about two } \\
\text { years); increasingly wider } \\
\text { crawling bands ( } 15 \text { years) }\end{array}$ & $\begin{array}{l}\text { Peg to horizontal band (about } \\
\text { two years); horizontal band to } \\
\text { increasing wider crawling } \\
\text { bands (two years); crawling } \\
\text { bands to de facto float within } \\
\text { an increasingly wider crawling } \\
\text { fan (six year); de facto to } \\
\text { formal free float (eight years) }\end{array}$ & $\begin{array}{l}\text { Crawling peg to crawling band } \\
\text { (four years); crawling band to } \\
\text { increasingly wider bands and } \\
\text { float (five years) }\end{array}$ & $\begin{array}{l}\text { Horizontal band to crawling } \\
\text { band (four years); crawling } \\
\text { band to free float (5) }\end{array}$ \\
\hline
\end{tabular}

\section{Examples from country experiences on supporting conditions for flexibility}

- Developing a deep and liquid FX market. Central banks stimulated FX market development by allowing some exchange rate flexibility through widening of trading bands; reducing their role in the market, and removing obstacles to market activity. The presence of other complementary financial markets, including liquid and efficient short-term interbank money and government securities markets, was also an important factor in the creation of deep, liquid derivatives markets for hedging. When liberalizing derivative transactions, the authorities established some precautions, such as prudential and supervisory rules to mitigate excessive risk taking.

- Capacity to monitor, regulate, and manage exchange rate risks. In most countries, the private sector had a reasonable capacity to manage FX risk exposure at the time of the float. Monitoring involved strengthening the prudential and supervisory framework; explicit regulation and reporting of banks' FX exposures; the incorporation of FX exposures in capital requirements; maintenance of FX liquidity requirements; and stress testing of indirect FX exposures in some cases.

- An alternative nominal anchor and monetary policy framework. The adoption of fullfledged inflation targeting (IT) frameworks followed lengthy transition periods, but the operational capacity to affect short term interest rates was generally well advanced when moving to a free float. Establishing monetary policy implementation capacity was important, and efforts to establish this typically began well before the introduction of flexibility, though 
they were by no means complete before the float. Reasonably well-developed financial markets supported the interest rate channel of monetary transmission. Most central banks fostered the development of well-functioning, liquid securities and interbank money markets by reducing the issuance of nonmarketable securities; using central bank bills and other marketable securities for monetary operations; creating an appropriate infrastructure; setting standards (for example, for repurchase (repo) contracts, reference rates); and deregulating markets (for example, by removing credit ceilings and liberalizing deposit-loan rates).

- Transparency and communication. Determining the appropriate level of transparency in communicating the exchange rate strategy was an important challenge during the transition process. In general, countries chose to be more transparent in communicating the strategies (for both the overall intervention strategy and preparation for greater exchange rate flexibility) when faced with credibility problems. Also, abandoning undisclosed inner bands increased the transparency and credibility of monetary policy and intervention strategies. In Poland, regime changes were communicated in advance, to provide market participants with time to prepare for the new regime, whereas operational decisions were conveyed to the public the day before or were not announced at all, thus helping avoid speculative activities. 